\title{
THE TROUBLES WITH CUPOLAS
}

\author{
TEŽAVE S KUPOLAMI \\ R. ARMSTRONG L. OSBORNE ${ }^{1}$
}

${ }^{1}$ School of Development and Learning, A35, University of Sydney, N.S.W. 2006, Australia, e-mail: a.osborne@edfac.usyd.edu.au 


\begin{abstract}
UDC: 911.2:551.435.8

R. Armstrong L. Osborne: The troubles with cupolas

Cupolas are dome-shaped solution cavities that occur in karst caves, and have been described in both limestone and gypsum karst. While there has been considerable discussion in the literature concerning the likely origin and significance of these features, there has been little in the way of detailed description of the features themselves and little attention has been given to the definition of the term. Consequently, there are a number of troubles with cupolas: - What is a cupola? Where do cupolas occur? What are cupolas like? Do cupolas occur with particular types of speleogens? Are cupolas features of ceilings or features intersected by ceilings? How do cupolas form? But how can these troubles be resolved? Tentative answers are given here to many of these questions but a great deal of basic field observation and theoretical work is required to solve them. The most important step would be more field observation and measurement of cupolas and of the particular suite of speleogens that occur with them. The troubles with cupolas can be solved and in the process we will come to understand a great deal more about the unusual caves in which they occur.
\end{abstract}

Key words: speleology, cave morphology, cupola.

Izvleček

UDK: 911.2:551.435.8

\title{
R. Armstrong L. Osborne: Težave s kupolami
}

Kupole so korozijske tvorbe v obliki kupol, znane tako s krasa v apnencih kot tudi v anhidritih. Medtem ko je bilo $\mathrm{v}$ literaturi precej razpravljanja o verjetnem nastanku in pomenu teh oblik, pa je zelo malo podrobnih opisov teh oblik ter definicij tega pojma. Zato je s kupolami precej težav: Kaj je kupola? Kje se kupole pojavljajo? Kakšne so kupole? Ali so kupole povezane z določenimi drugimi oblikami? Ali so kupole oblike v stropu ali oblike, ki jih je strop prerezal? Kako kupole nastajajo? Kako lahko rešimo ta vprašanja? V prispevku je veliko odgovorov na ta vprašanja, toda večji del terenskih raziskav in teoretičnega dela bo treba šele opraviti. Najpomembnejša so podrobna terenska opazovanja in merjenja kupol ter tistih oblik, ki so z njimi povezane. Tako bo mogoče rešiti vprašanje kupol in tako bo mogoče izvedeti še več o nenavadnih jamah, v katerih se kupole pojavljajo.

Ključne besede: speleologija, jamska morfologija, kupola. 


\section{INTRODUCTION}

Cupolas appear to be common features of uncommon caves. There has been much speculation about how they have formed, but little description of what they are like. The term is poorly defined and different workers seem to use the term to describe quite different things. There are, as a consequence, a number of troubles with cupolas.

This paper is not concerned as much with how cupolas form or what they can tell us about the caves in which they occur, rather it discusses these problems, offers solutions to some and outlines a process by which other problems might be resolved.

\section{THE TROUBLES WITH CUPOLAS}

\section{What is a Cupola?}

Most would agree that cupolas are dome-shaped solution cavities that occur in some limestone and gypsum caves. Despite their significance to speleogenetic arguments, the term "cupola" does not occur in most international glossaries on caves and karst (e.g. Field, 1999, Panos, 2001) except in the sense of a hemispheric hill.

As a consequence, different workers apply the term cupola to a great range of features. These range from small ceiling pockets $0.5 \mathrm{~m}$ or less in diameter to large chambers tens of metres in diameter and height, such as the Temple of Baal at Jenolan Caves, NSW, Australia which is $50 \mathrm{~m}$ in diameter and $45 \mathrm{~m}$ high. While most workers use some form of morphological definition, Alexander Klimchouk (pers comm. 2001) talks about cupolas as functional entities that allow the passage of water from an artesian cave into an overlying aquifer. These outlet cupolas are not dome-shaped, but are vertical to sub-vertical tubes that frequently narrow as they rise.

There are many examples of ceiling domes and dome-shaped cavities produced by breakdown, some of which are quite large. A good example is the Grosse Dom in Mammuthole, Austria. Klimchouk \& Andrejchouk (1996) described similar features in the gypsum caves of western Ukraine. Breakdown domes and large dome-shaped tafoni-like cavities are not considered here to be cupolas.

In (UK) English the word cupola has at least three distinct architectural meanings: -

1. a dome forming the roof of a building (Figure 1),

2. a small dome rising above a roof

and

3. the ceiling of a dome (Little et al., 1936).

A search of the internet will show that at least in current US usage the second meaning has become dominant, with many web sites dedicated to the construction of roof ventilation structures called cupolas (Figure 2).

While dome has become the most used English geometric and architectural term for " a large hemispherical, approximately hemispherical or spheroidal vault"(Delbridge, 1981), cupola is the older term. As Fletcher (1950) explained: - "Dome (It. doumo = a cathedral from Lat. domus = a house). - The custom in Italy was to erect cupolas over churches, and the word "dome" has passed in English and French from the building to this form of roof." [Fletcher, 1950 p 969].

While there has been considerable documentation of small dome shaped structures less than $1.5 \mathrm{~m}$ in diameter, called "bell holes" (Dogwiler, 1998), "ceiling pockets" or "kolks" (Dreybrodt 


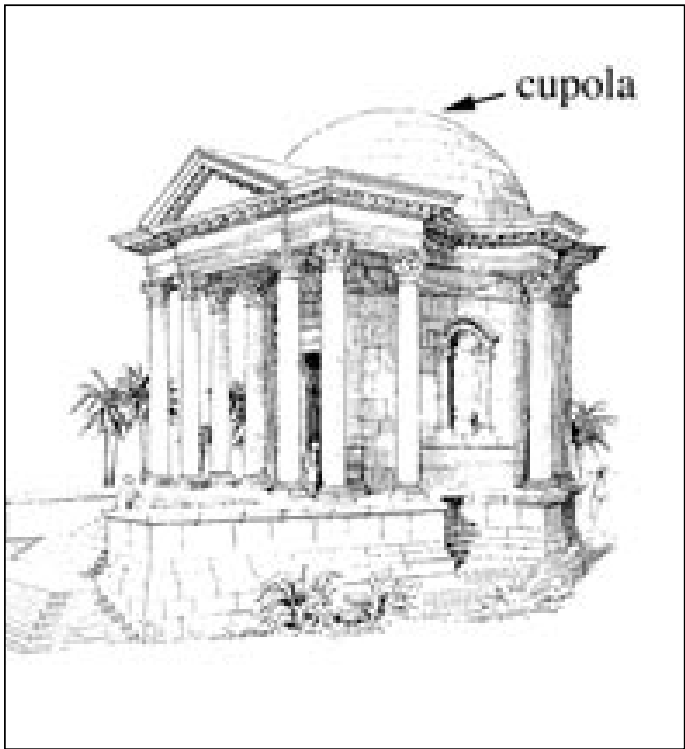

Fig. 1: The Temple of Venus at Baalbek showing cupola from Fletcher (1950) p160.

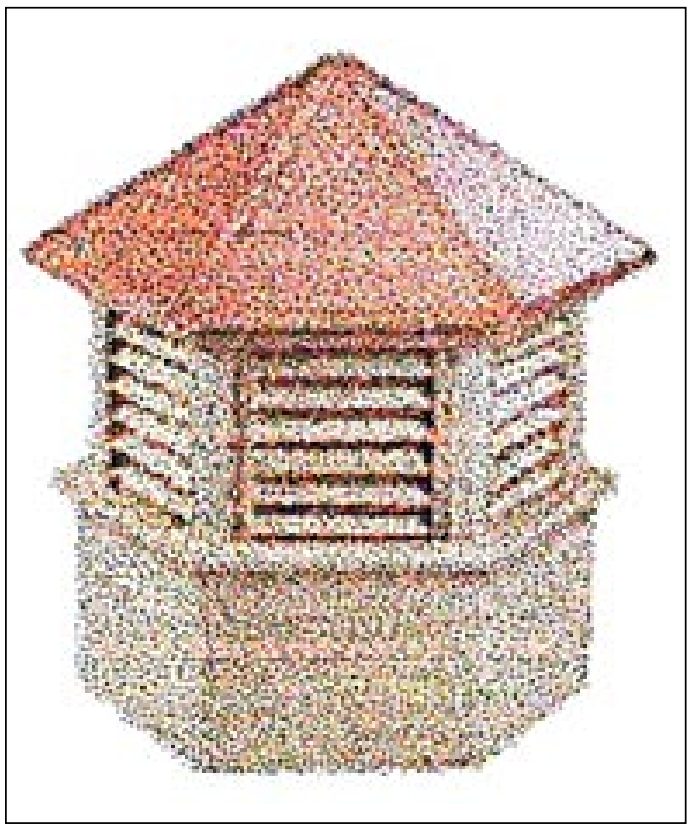

Fig. 2: A cupola (roof ventilation structure) after a US advertising website.
\& Franke, 1994), very little in the way of documentation has been made, however, of dome-shaped features more than $1.5 \mathrm{~m}$ in diameter. The outstanding exceptions are descriptions from Polish caves by Gradzinski, (1962), from Belgian caves by Quinif (1973) and from Polish and Hungarian caves by Rudnicki (1978). Bögli (1980) used the term "inverse solution pockets" to describe ceiling pockets that range in size from " a few centimetres to many metres" and ascribed their formation to mixing corrosion. Bögli's "inverse solution pockets" would include both bellholes and cupolas.

Lauritzen \& Lundberg (2000) give one of the few published definitions of the term cupola (p 415) as follows: -

"Spherical or semispherical enlargements that are greater than, or similar to, the diameter of the passage leading into them, are named cupolas."

The problem with this definition is that many features commonly called cupolas would not qualify because they are developed in, or intersected by, the ceiling of large diameter passages. In order to overcome this problem and to make a distinction, although arbitrary, between cupolas and bellholes I have chosen the following operational definition as a starting place for further discussion: -

A cupola is a solution cavity with a dome-shaped ceiling and a circular to elliptical plan with a diameter or long axis in plan $>1.5 \mathrm{~m}$.

This is intended to exclude bellholes and breakdown domes, but to include as many of the features as possible that a range of workers has called cupolas. The use of cupola here is probably equivalent to "solution dome" used by Hill (1987, p 31). 


\section{Are Cupolas whole chambers or just the domes?}

Architects recognise that domes need to be supported. Thus high domes sit on a structure called a barrel (Figure 3). In the case of cupolas in caves does the term refer only to the dome itself or are cupolas whole chambers with domed ceilings? This is not a trivial issue because if only the dome is considered then most of the void currently included as part of the cupola would be left out.

It seems most useful to take the view that in the case of caves, a cupola (where not developed in, or truncated by a flat ceiling) is the whole of a chamber with a domed ceiling (i.e. dome, barrel and floor).

\section{What are Cupolas Like?}

The few cross-sections of cupolas that have been published give little indication of the shape and dimensions of cupolas. Most papers only give a section along one axis. Sections of cupolas made incidentally during conventional cave mapping are also inadequate. Naked eye and casual photographic observations suggest that cupolas have a range of profiles. Some are hemispherical domes, some have a downward tapering tear drop or wine glass profile, while others are wider at the base than the top. Some are circular in plan, while others are distinctly elliptical.

Before commencing detailed field measurements I had a clear idea of what cupolas looked like, this is shown in Figure 4 which was produced during an unscheduled night's stopover in a regional motel in 2001. My initial sections with distances measured using a laser rangefinder showed however that there may be some disjunction between our visual perception of cupolas, on which Figure 4 is based, and their true shape. This can be seen in Figures 5 and 6 .

Many features that appear to the naked eye to be globular, (e.g. the Persian Chamber, Figure 7) on survey turn out to be more cylindrical than imagined, with almost perpendicular walls supporting a domed ceiling. Similarly hollows in walls, as in Figure 6, are frequently misinterpreted as ceiling domes. Thus naked eye impressions and photographs presented

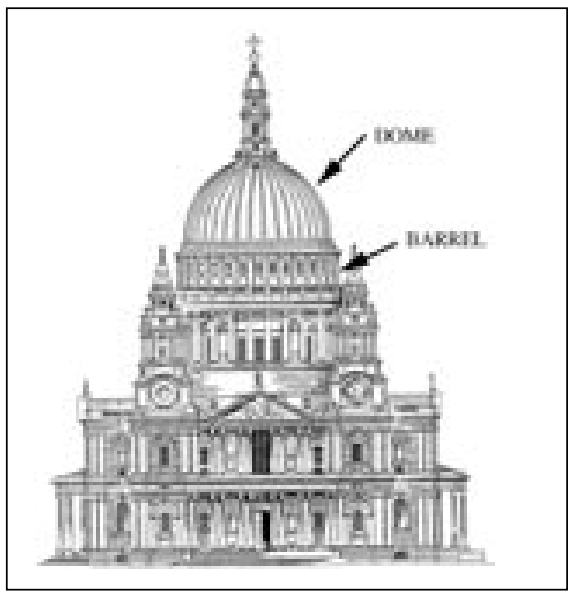

Fig. 3: A dome and barrel, St Paul, London after Fletcher (1950) p160 p 801.

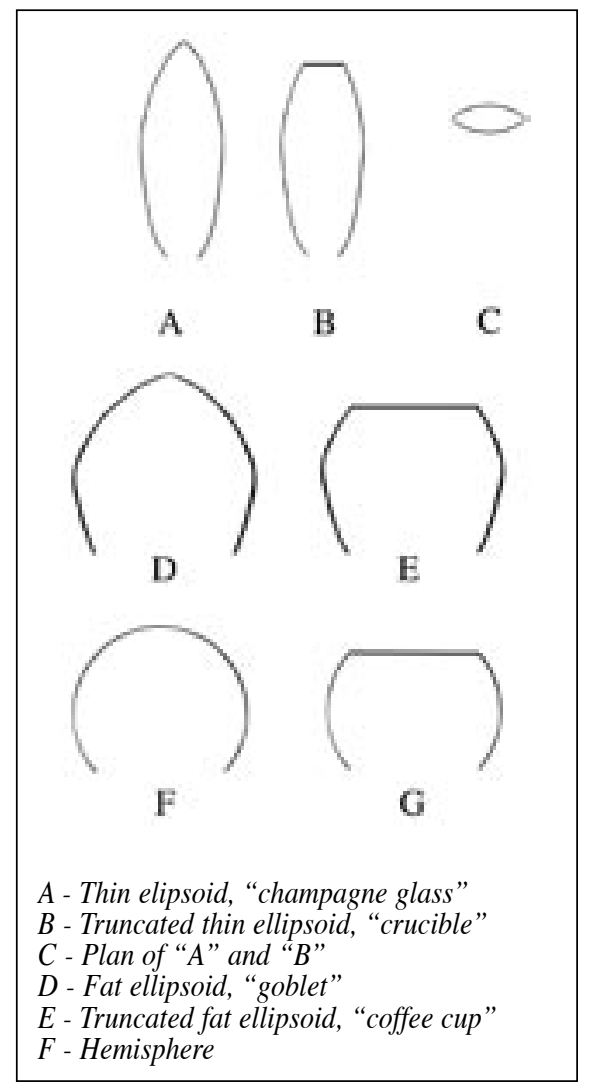

Fig. 4: Initial cupola concepts. 
without orientation data are probably responsible for cylinders or elliptical tubes supporting domes being interpreted as "A" and "D" in Figure 4.

Many more measured sections and oriented images are necessary before this question can be properly answered. Initial work suggests that at least five general types of cupolas can be recognised.

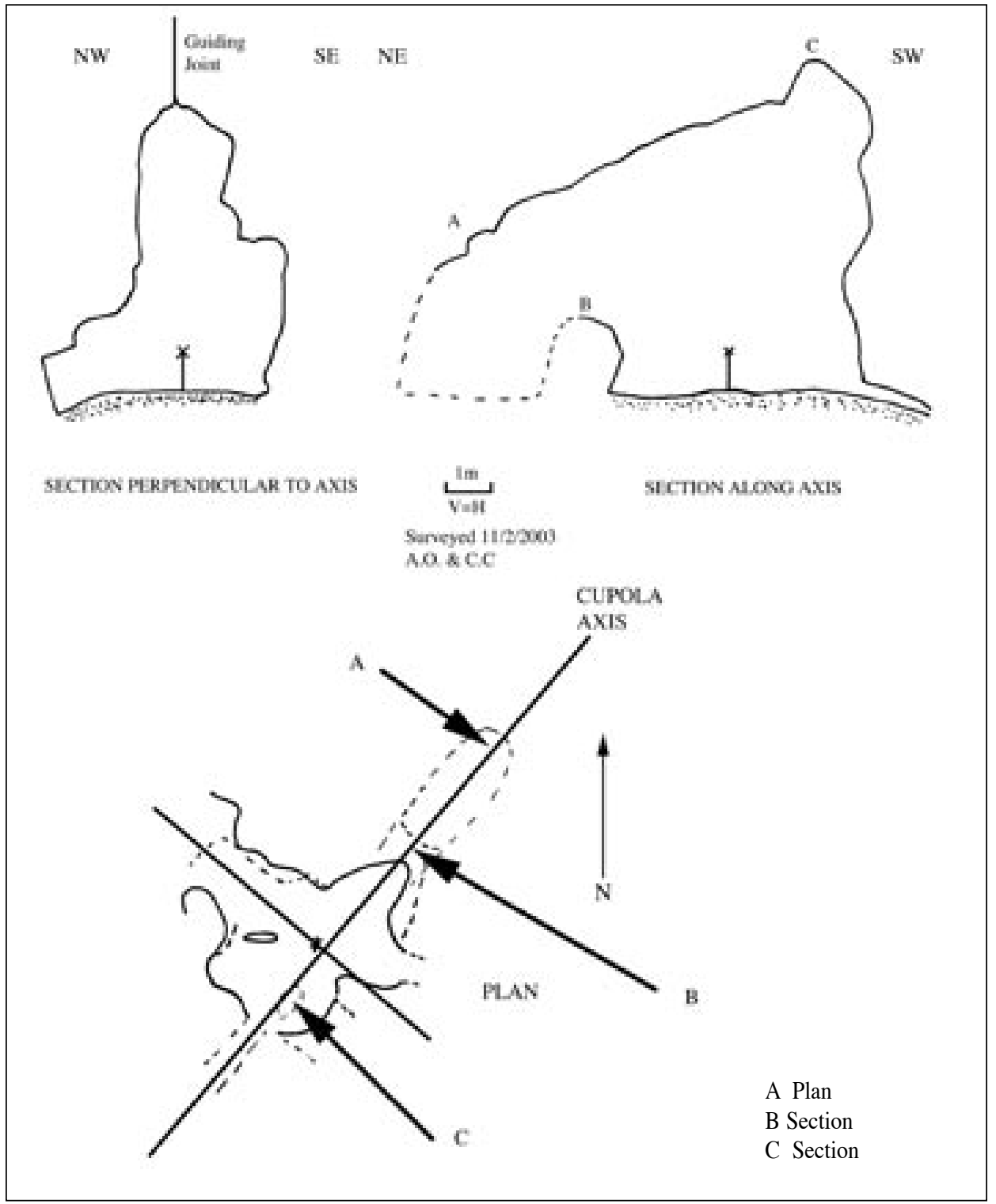

Fig. 5: "Kissing Cave" an elliptical cupola in Cathedral Cave, Wellington Caves NSW Australia. 


\section{What general types of cupolas can be recognised?}

The five types of cupolas that can be readily recognised are; elliptical cupolas, cathedrals, hemispherical cupolas (Figure 8), conical cupolas and spherical niches. While the first three fit well within the operational definition given above, conical cupolas and spherical niches are frequently smaller than $1.5 \mathrm{~m}$ in diameter, and there are grounds in the case of spherical niches to consider them to be speleogens or rocky-relief features rather than chamber-sized voids.

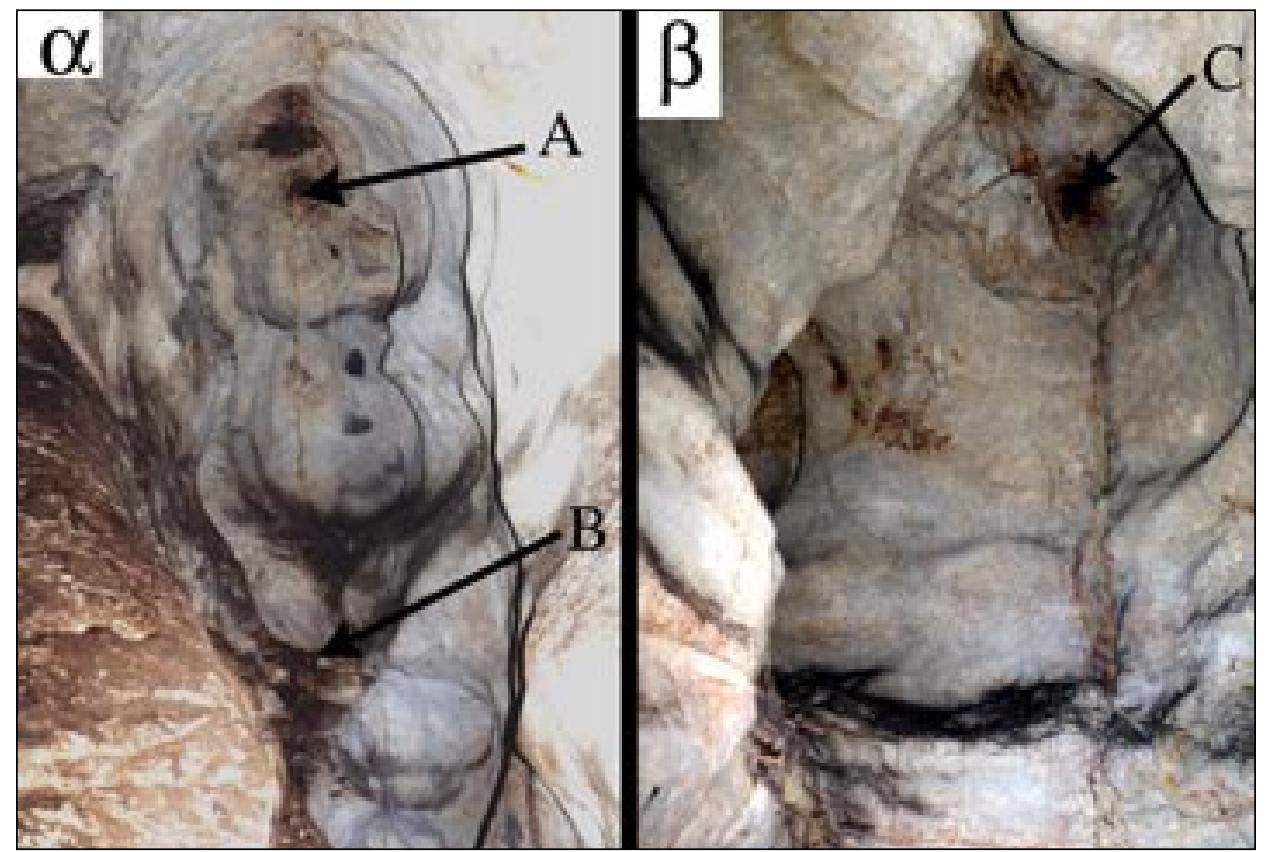

Fig. 6: Photos of "Kissing Cave”.

$\alpha$ Looking NE. The location of " $A$ " and " $B$ " are shown in Figure 5.

$\beta$ Looking SW. The location of" " $C$ " is shown in Figure 5.

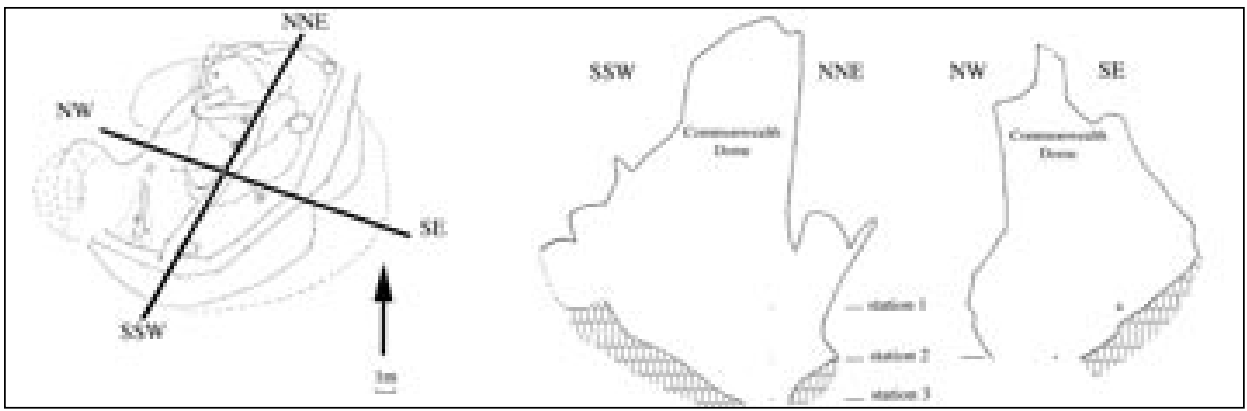

Fig. 7: Plan and two sections of the Persian Chamber, Orient Cave, Jenolan Caves, New South Wales, Australia. Note how much of the northwestern wall of the chamber is vertical and how the "Commonwealth Dome" only makes up the upper quarter of the known height of the chamber. 


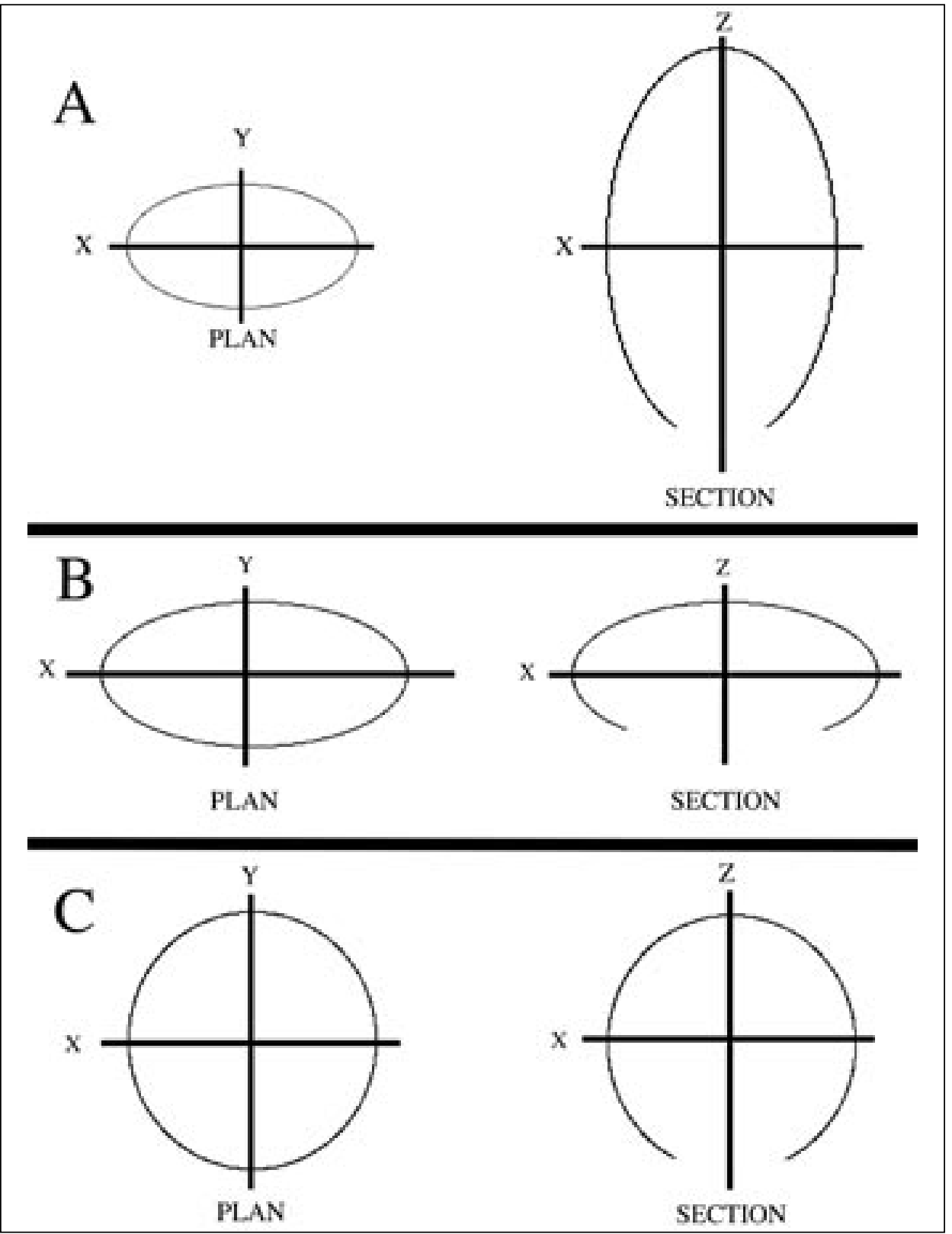

Fig. 8: Comparison of elliptical cupolas, cathedrals and hemispherical cupolas.

A Elliptical cupola, $\mathrm{X}>\mathrm{Y}, \mathrm{Z} \geq \mathrm{X}$.

B Cathedral, $\mathrm{X}>\mathrm{Y}, \mathrm{Z} \geq \mathrm{Y}, \mathrm{NB}$ Reduced scale, Cathedrals are much larger than most elliptical and hemispherical cupolas.

C Hemispherical cupola, $\mathrm{X}=\mathrm{Y}=\mathrm{Z}$. 


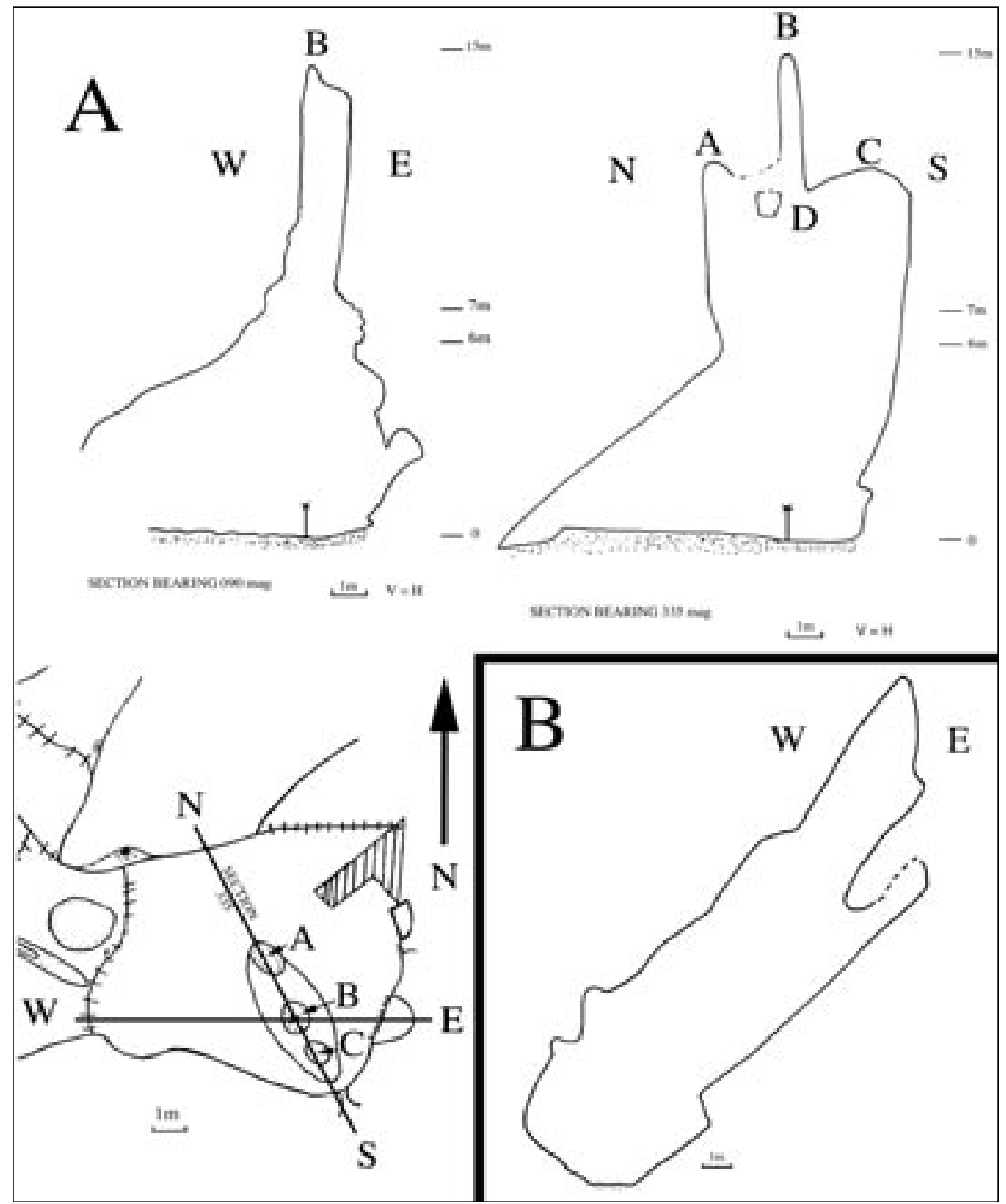

Fig. 9:

A Plan and two sections of an elliptical cupola in Cathedral Cave, Wellington Caves, New South Wales, Australia.

Note: 1 . how the cupola form starts about $6 \mathrm{~m}$ above the cave floor

2. the development of 3 bellhole-like centres "A", "B" \& "C" in the ceiling of the cupola.

3. the rock bridge at " $D$ "

4. the almost vertical walls above $6 \mathrm{~m}$ in the N-S section.

B Section of an elliptical cupola with non-vertical axis, developed in westerly-dipping bedrock, the Mud Tunnels, River Cave, Jenolan Caves, New South Wales Australia. 


\section{Elliptical Cupolas}

Elliptical cupolas are generally elongated along a guiding structure, which I have called a propagation plane. Propagation planes are usually joints (Figure 9A), but in steeply dipping limestones they may be beds. While propagation planes are often vertical, elliptical cupolas can develop along dipping structures (Figure 9B).

Measurements made so far suggest that elliptical cupolas have a length to width ratio ranging from just elliptical up to 4:1 as in the case of the middle part of the cupola in Figure 8A. It would

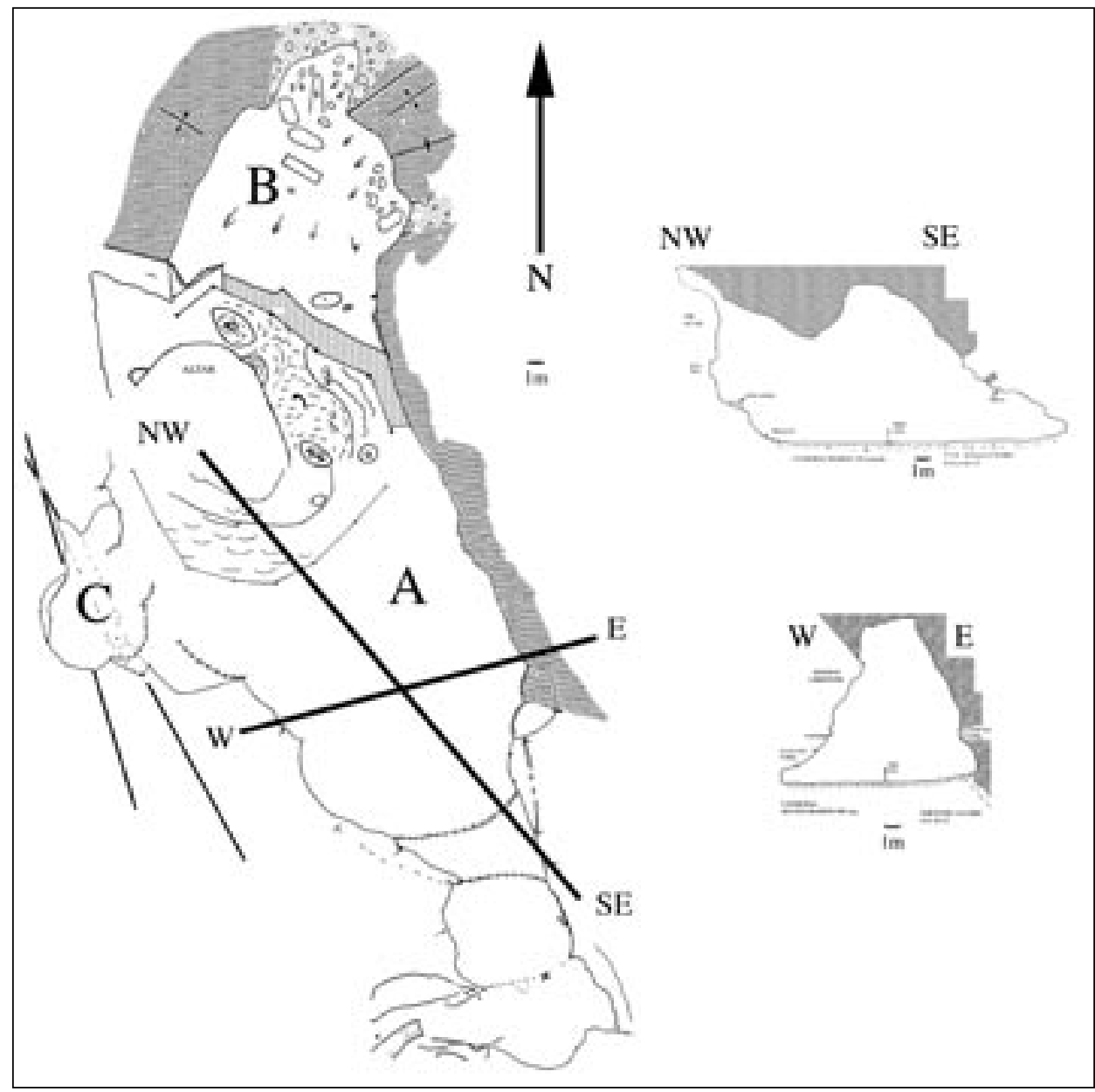

Fig. 10: A Cathedral, plan and sections of The Cathedral, Cathedral Cave, Wellington Caves, New South Wales, Australia. The chamber is developed at boundary between massive and thinly bedded (small brickwork on figure) limestone. The chamber consists of two cathedrals "A" (NW-SE axis) and " $B$ " $(N-S$ axis) and an elliptical cupola " $C$ " (NW-SE axis). The guiding structure of cathedral " $A$ " is not the boundary between the two lithologies, but a vertical joint that cuts through both. Note the triangular, rather than globular profile of the cross-section. 


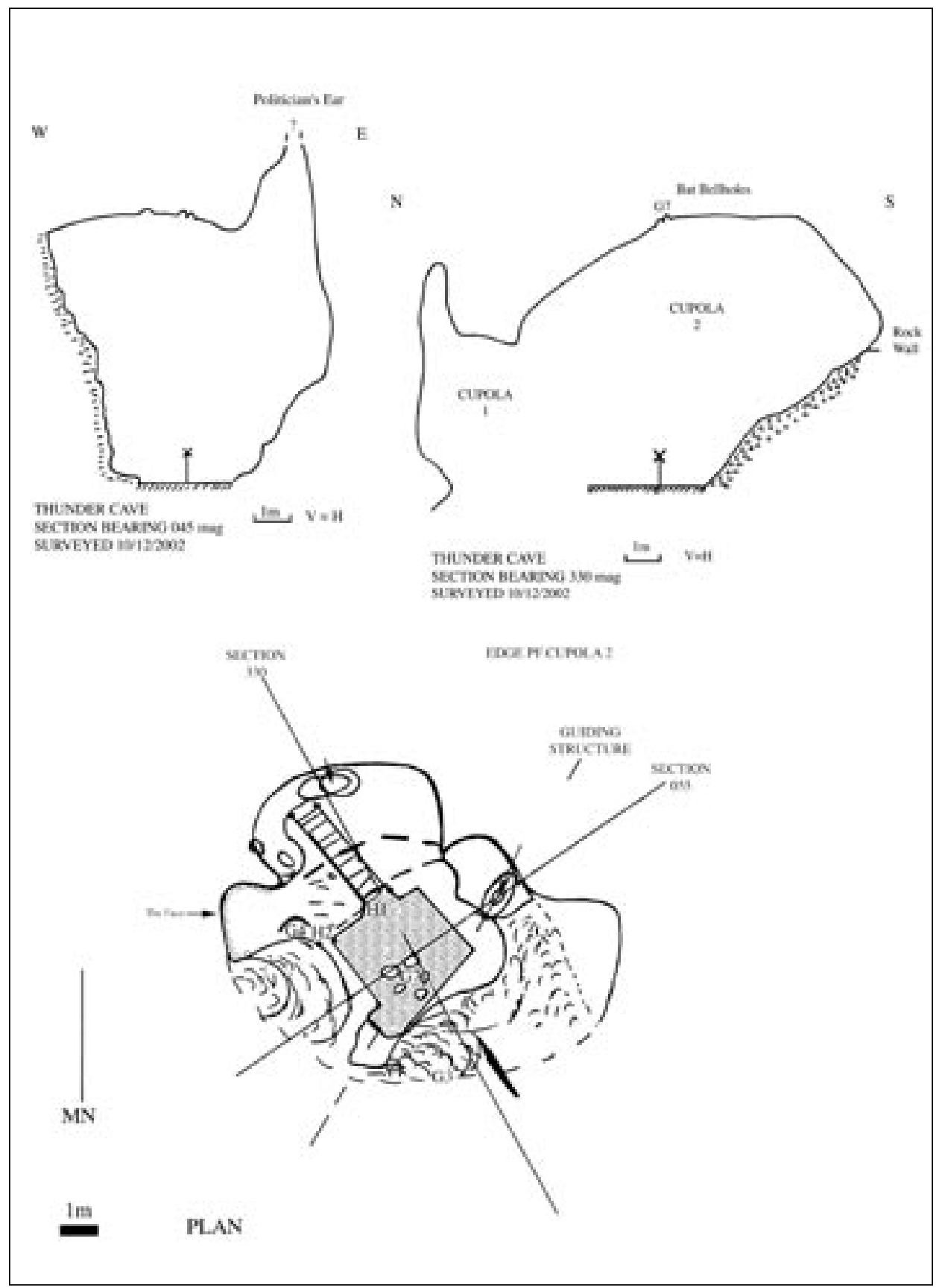

Fig. 11: Thunder Cave, Cathedral Cave, Wellington Caves, New South Wales, Australia a pair of hemispherical cupolas with an elliptical conical cupola the "Politician's Ear" and bellholes. 
be useful to see if length to width ratios can be used to distinguish between hemispherical and elliptical cupola types and if there is a particular ratio at which the presence of a guiding structure becomes more common. Elliptical cupolas generally to have a more pronounced vertical ( $\mathrm{z}$ axis, Figure 8) than horizontal development. More measurement and analysis of elliptical cupolas and their relationships with their propagation planes is required.

\section{Cathedrals}

Large elliptical cupolas that appear to have a longer horizontal than vertical axis have been observed at two locations in Australia (Naracoorte and Wellington) and in Tapolca Lake Cave, near Lake Balaton, Hungary. The Australian examples both occur in caves called "Cathedral Cave" (Figure 10). Cathedrals are tens of metres long and ten metres or more wide.

In all three cases the cathedral floor is filled with sediment, so their true height is unknown. In the case of Cathedral Cave at Wellington palaeontological excavations in the 19th century showed that the sediment in the floor is at least $10 \mathrm{~m}$ deep. This suggests that cathedral "A" in Figure 9 is likely to be $30 \mathrm{~m}$ long x $15 \mathrm{~m}$ wide x $25 \mathrm{~m}$ high.

\section{Hemispherical Cupolas}

Hemispherical cupolas are characterised by a circular plan and a hemispherical cross-section making them true domes in the geometric sense. While hemispherical cupolas appear to be common forms where cupolas are developed in, or intersected by, flat cave ceilings, my initial studies in eastern Australia indicate that hemispherical cupolas are far less common than elliptical cupolas where the cupola is preserved as an entire void.

Hemispherical cupolas do not appear to be obviously guided by geological structures. They may however form part of a complex of voids that include both hemispherical and elliptical or conical cupolas. Figure 11 shows a plan and sections of Thunder Chamber in Cathedral Cave, Wellington Caves NSW. This cavity consists of two conjoined hemispherical domes; a set of paired bellholes and a joint-guided conical cupola the "Politician's Ear".

\section{Conical Cupolas}

Conical cupolas are usually elongate features with a basal diameter or long axis of $2 \mathrm{~m}$ or less and a vertical axis extending for several metres. Conical cupolas may be circular or elliptical in plan. Figure 12A shows a conical cupola with circular plan in the Pool of Cerberus Cave at Jenolan Caves.

Conical cupolas are found in both limestone and gypsum caves. In gypsum and in some thermal caves they likely to be interpreted as "outlet" structures (Figure 12B), while in limestone caves they are likely to be interpreted as mixing corrosion features because they show penetration into the guiding joint.

While I have yet to make detailed measurements of conical cupolas, naked-eye field observations and examination of photos suggest that there is no obvious morphological difference between conical "outlet" cupolas in gypsum caves and conical "mixing corrosion" cupolas in limestone caves.

\section{Spherical Niches}

Spherical niches are a rare form of void reported from Sátorköpuszta and Batöri caves in Hungary and from caves in Koloczek Hill near Krakow in Poland (Figure 13A) (Rudnicki, 1978). In Sátorköpuszta Cave they are spherical voids approximately 1-2 $\mathrm{m}$ in diameter, frequently connected to the rest of the cave by an opening at an angle of about 45 degrees to the perpendicular (Figure 13B). Most workers have not used the term cupola to describe these features, however Lauritzen \& 
Lundberg (2000) called the spherical niches in Sátorköpuszta Cave cupolas.

The spherical niches in Sátorköpuszta Cave join at their necks to form a complex spongework in the central vertical axis of the cave and project outwards and upwards from the axis to produce an overall form not unlike an upside-down bunch of grapes. More conventional forms of cupola occur in the upper sections of Sátorköpuszta Cave. It is unclear whether spherical niches should be considered a special type of cupola or a large speleogen rarely found associated with cupolas.

\section{What are the lower parts of cupolas like?}

While cupolas may be common in caves that contain little fluvial sediment, many cupolas contain large quantities of speleothem and others (all of the cathedrals so far recognised) have flat floors resulting from the accumulation of sediment. This means that in most cases accumulated sediment and speleothem obscure the true shape of the void.

None of the sections measured so far show the true shape of the lowest parts of the cupolas, making comparison with ideal forms such as those in Figure 4 impossible. It is not known then if cathedrals form closed ellipses in cross-section or if elliptical cupolas extended along the vertical axis close at the lower apex of their long axis as shown in Figure 8.

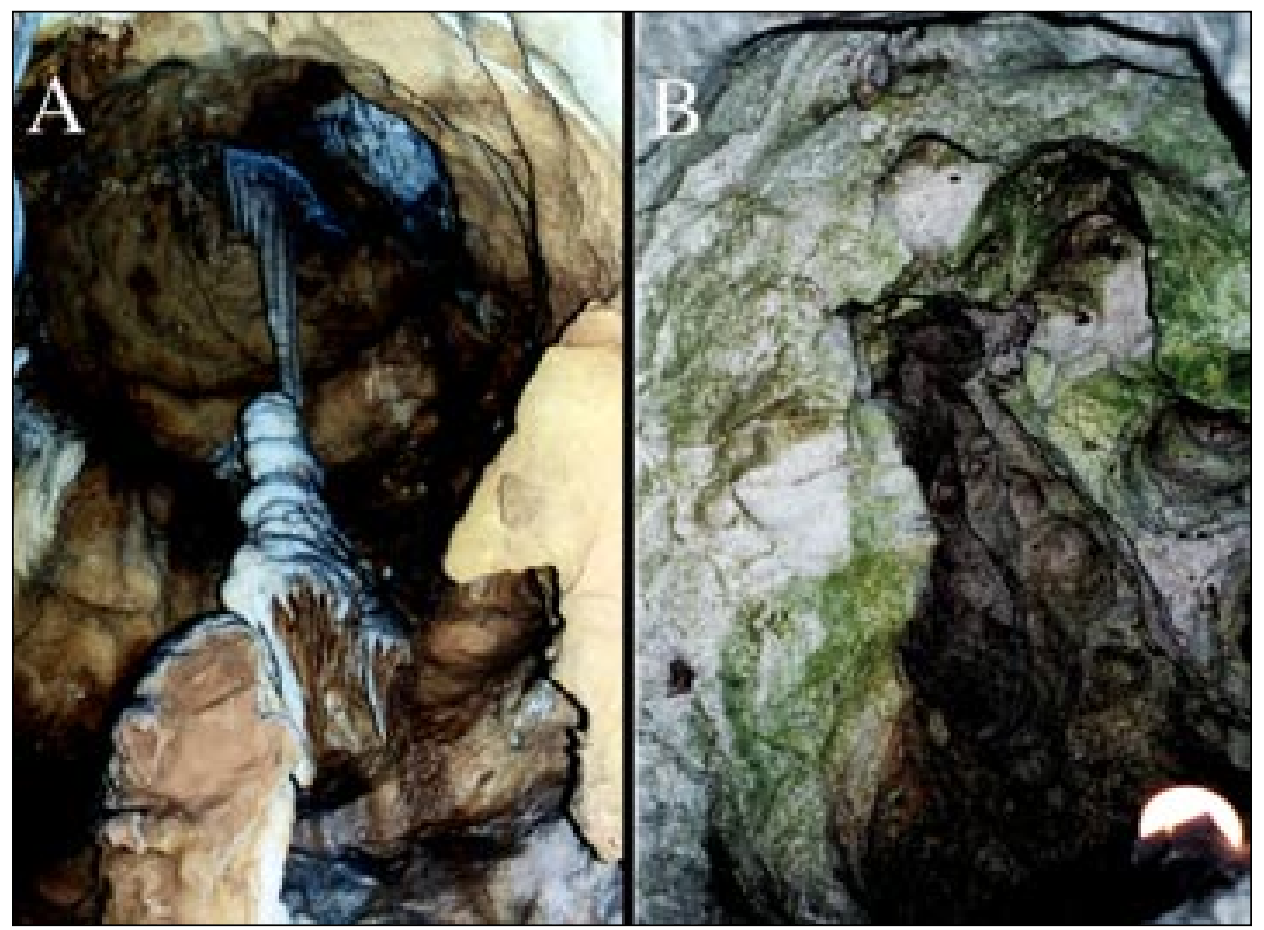

Fig. 12: Conical and "outlet" cupolas

A A circular conical cupola developed in massive Silurian limestone in the Pool of Cerberus Cave, Jenolan Caves, New South Wales, Australia. Photo looking up. Basal diameter of cupola is approximately $2 \mathrm{~m}$. Note niches and large wall cusps/scallops.

B An outlet cupola, Smocza (Dragon's Den) Cave, Krakow, Poland. 


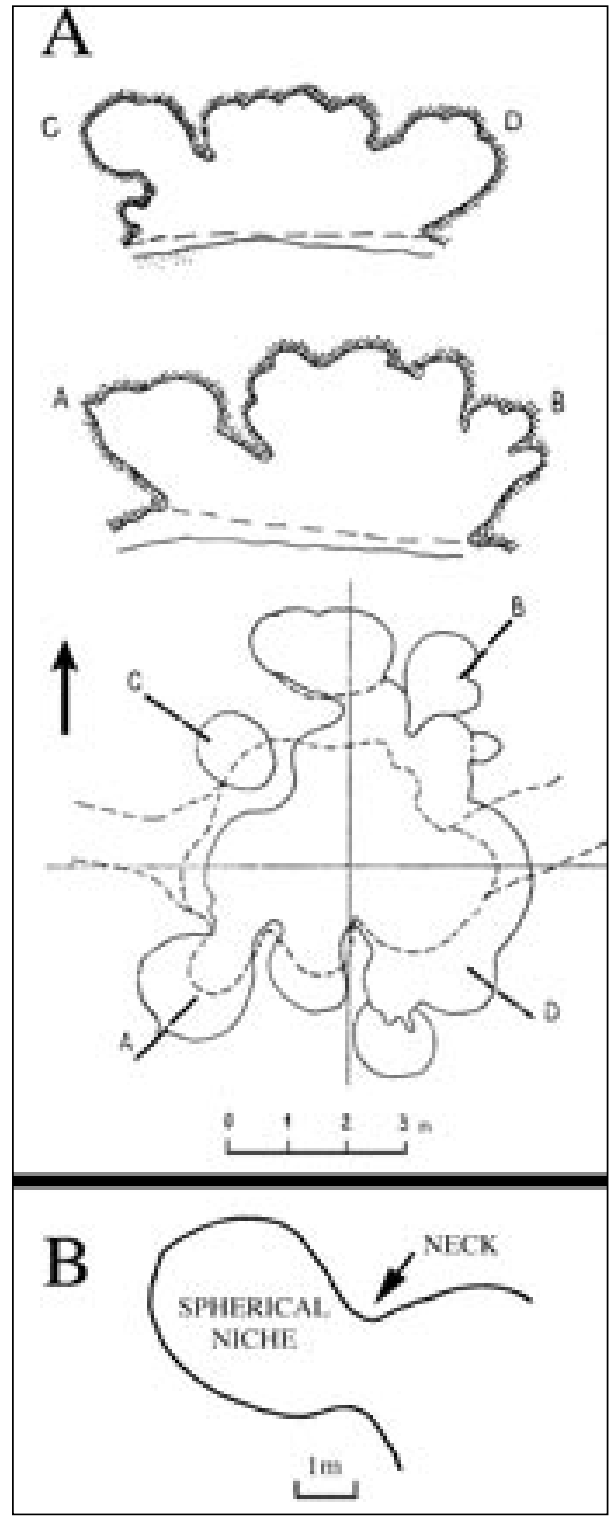

Fig. 13:

A Plan and sections of a cave with spherical niches in Koloczek Hill, near Krakow, Poland from Rudnicki (1978) Figure 1. From Kras I speleologia 2(XI) $p 93$ reproduced by courtesy of editors.

$B$ A spherical niche. Based on field sketch and measurements, Sátorköpuszta Cave, Hungary, September 16, 2001. Note inclined axis of sphere.
In sediment-filled situations this may be resolved by use of ground penetrating radar, but in many cases we will never know the complete shape of cupolas as only their upper parts are preserved, their lower sections removed by later cave development.

\section{Where Do Cupolas Occur?}

Cupolas are uncommon in stream caves and are only found as features developed in or intersected by the cave walls or ceilings. Cupolas appear to be most common in caves with known or suspected thermal, hydrothermal, artesian, hypogene or mixed water origins, and in caves that are thought to have complex multiphase, multiprocess origins.

Table 1 gives a list of caves I have been able to identify from the literature and from reliable personal sources that contain cavities fitting the definition of cupola given here.

The large number of reports from continental Europe (Figure 14) may represent a real natural abundance, but also may result from a scientific tradition that has long accepted the idea of caves having non-meteoric origins. I suspect that a combination of both factors is involved. Since cupolas do not rate a mention in most glossaries, nor are they mentioned in many standard texts, the traditional bias is likely to be strong. Proximity to specialists with access to the central European literature, as well as natural clustering is probably influencing other regional concentrations. The scarcity of cupolas in Slovenian caves does appear to be real and probably results from the dominance of meteoric, per descensum speleogenetic process in the region.

Art Palmer provided Figure 15, showing cupola locations in the USA. The concentration towards the centre and west of the country is interesting, with none reported from the Appalachian Fold Belt. Whether this reflects the true situation or is an artefact of reporting is not known. It is an interesting contrast however with 


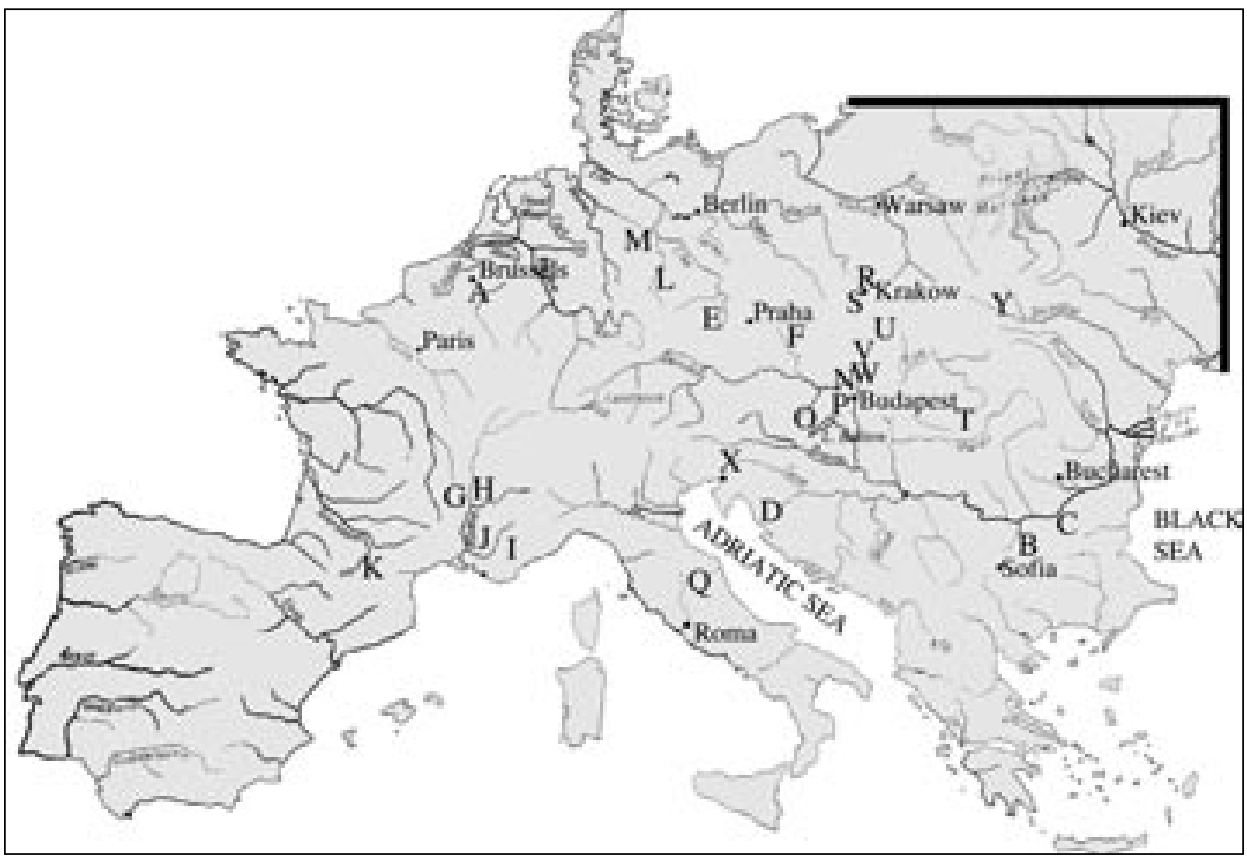

Fig. 14: Map of Europe showing cupola localities.

$\begin{array}{ll}\text { A } & \text { Somme-Leuze, Belgium } \\ B & \text { Karloukovo, Bulgaria } \\ C & \text { Dobroudja, Bulgaria } \\ D & \text { Plitvice, Croatia } \\ E & \text { Bohemia, Czech Republic } \\ F & \text { Moravia, Czech Republic } \\ G & \text { Ardèche, France } \\ H & \text { Isère, France } \\ I & \text { Provence, France } \\ J & \text { Vaucluse, France } \\ K & \text { Ariège, France } \\ L & \text { Vogtland, Germany } \\ M & \text { Hartz, Mts., Germany } \\ N & \text { Pilisz Mts., Hungary } \\ O & \text { Lake Balaton, Hungary } \\ P & \text { Buda Hills, Hungary } \\ Q & \text { Umbria/Marche, Italy } \\ R & \text { Krakow, Poland } \\ S & \text { Tatra Mts., Poland } \\ T & \text { Bihor Mts., Romania } \\ U & \text { Belianska Tatra, Slovakia } \\ V & \text { Low Tatra, Slovakia } \\ W & \text { Ochtinska cave, Slovakia } \\ X & \text { Kras, Slovenia } \\ Y & \text { Western Ukraine }\end{array}$


eastern Australia where most of cupola locations are in the Tasman Fold Belt, which is said to be tectonically similar to the Appalachians.

Cupola locations in Australia are shown in Figure 16. The pattern is clearly influenced by proximity to my home-base in Sydney, however I am not seeing cupolas in every cave I visit. The concentration in steeply-dipping early Palaeozoic limestones of the Lachlan Fold Belt (part of the Tasman Fold Belt) in New South Wales is probably real. Lack of reporting in other areas does not necessarily mean however that cupolas are absent. The cupola locations in South Australia occur in a completely different tectonic setting. They are developed in the horizontally bedded Miocene limestones of the Otway Basin. The reason for the occurrence of cupolas in two such contrasting substrates and tectonic settings has yet to be investigated.

\section{Do cupolas occur with particular types of speleogens?}

Observations in central Europe and detailed work so far carried out at Jenolan and Wellington caves in New South Wales have shown that cupolas do not occur in isolation. They are associated with a suite of speleogens, most of which are different from those described by Slabe (1995), that

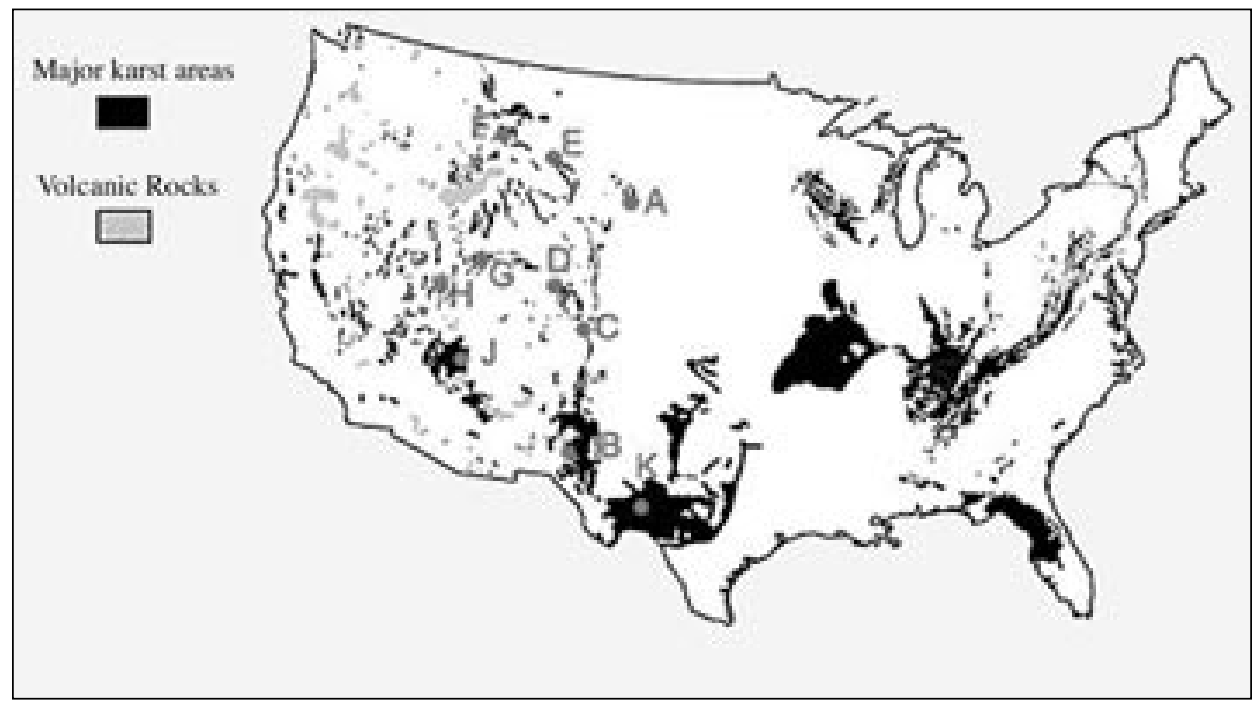

Fig. 15: Map of the USA supplied by Art Palmer showing cupola localities.

$A$

$B$

$C$

$D$

E

$F$

G

$H$

$J$

K
Black Hills (e.g. Jewel \& Wind), South Dakota

Guadalupe Mts., New Mexico

Rocky Mountain front, Colorado

White River Plateau, Colorado

Horsetheif-Bighorn System, Montana-Wyoming

Lewis and Clark Cave, Montana

Low elevation caves (e.g. Timpanoga), Utah

Nevada-Utah border (e.g. Lehman Cave), Nevada

Grand Canyon caves

Caverns of Sonora, Texas 
is they are different from speleogens found in typical stream caves.

Mylroie et al. (1995) noted that there were similarities between the wall morphology of flankmargin caves in carbonate islands that contain cupolas and caves from mixed-water situations such as the caves of the Guadalupe Mountains of New Mexico and the Black Hills of South Dakota.

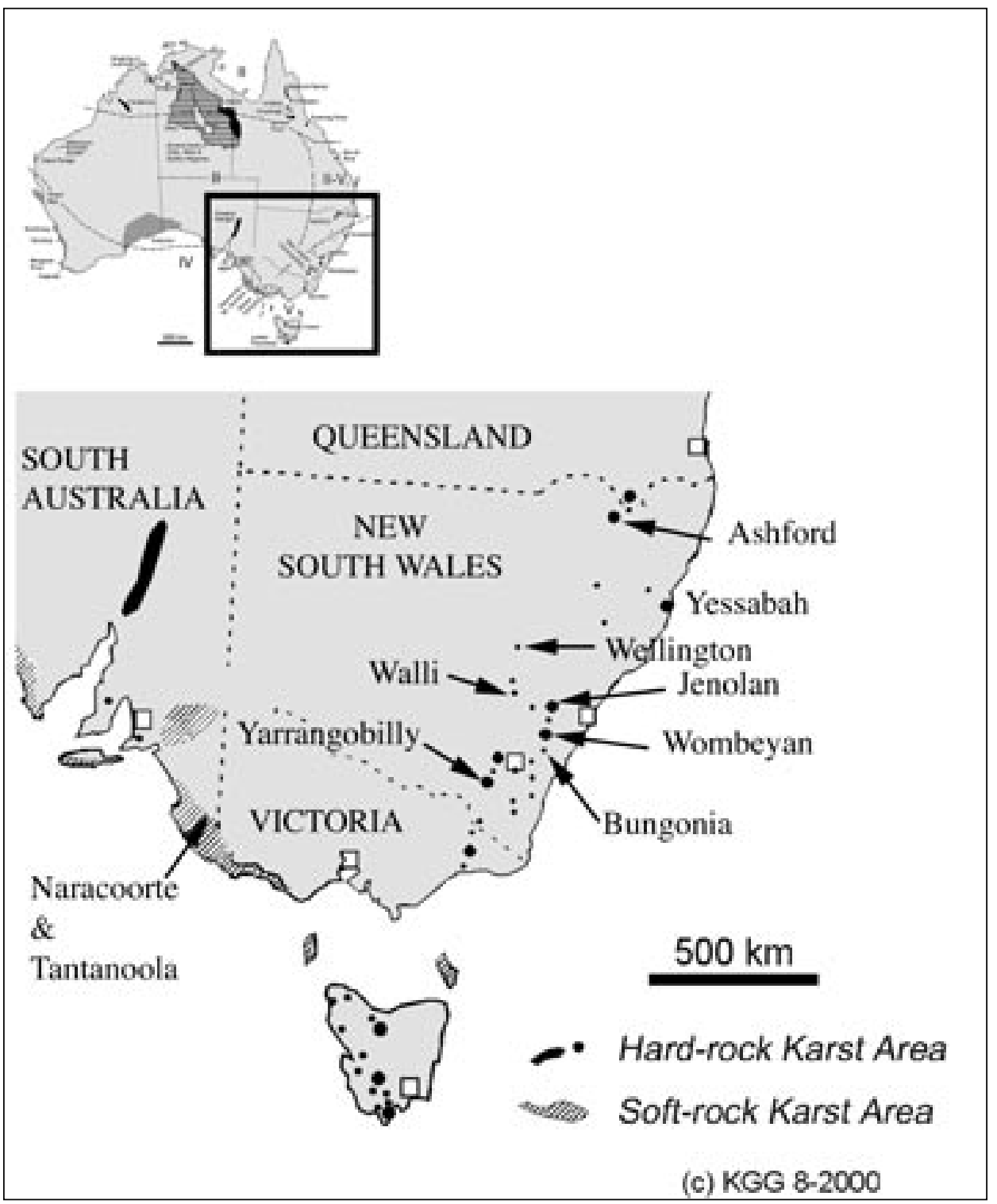

Fig. 16: Map of Australia showing cupola localities. Key map and map base copyright $\mathbb{C}$ KG Grimes, 2000, used with permission. 
I have also observed that cupolas, whatever the supposed origin of the cave in which they occur, are associated with speleogens that are similar to those reported from hydrothermal, thermal and artesian caves.

While this was apparent during reconnaissance observations in central Europe in 2001, initial detailed work at Jenolan and Wellington has confirmed this.

I have observed that cupolas are frequently associated with:

- $\quad$ blind passages (Halls of Osborne, 2001),

- ceiling half-tubes,

- rising half tubes,

- wall notches,

- symmetrical wall and ceiling pockets,

- very large scallops,

- rock bridges,

- cave walls with circular sections in plan view,

- curved wall, ceiling and floor projections (i.e. curved pendants, juts and floor blades),

- bellholes,

- symmetrical pits (approx. $40 \mathrm{~mm} \phi$ pits and approx. $10 \mathrm{~mm} \phi$ pits),

- Laughöhle passages (Kempe, 1975), with flat ceilings and inward sloping (facet) walls,

- caves that consist of an alternating series of high and low ceilings in long-section.

One form of speleogen that does seem to be particularly associated with cupolas does not appear to have been previously described. I have called this a Pseudonotch. Pseudonotches are elongated indentations in the cave wall, similar to a notch, but they are really a cave passage with a circular cross section that has been intersected or partially intersected by later cave development. Pseudonotches often are associated with bridges and may merge with bridges or with tubular passages that have not been intersected (Figure 17).

\section{Are Cupolas features of Ceilings or features intersected by ceilings?}

To the casual observer cupolas often appear to be features developed in cave ceilings. Detailed observations at Jenolan and Wellington however suggest that rather than being features of ceilings, cupolas are frequently the remnants of large voids that have been intersected by the ceilings of younger epiphreatic, paragenetic or Laughöhle passages.

The distinction between cupolas formed in ceilings and cupolas intersected by ceilings is difficult to make and is currently fairly subjective. Criteria need to be developed to assist with making this distinction. It is, however an important distinction to make as cupolas that have been intersected by ceilings must be relict features inherited from a prior phase of speleogenesis and are likely to have been excavated by mechanisms that are no longer active in the karst.

\section{How Do Cupolas Form?}

There has been considerable discussion in the literature concerning the likely origin of cupolas, with a range of origins suggested including: -

- $\quad$ solution by thermal/hydrothermal water (Bac-Moszaswill \& Rudnicki, 1978; Rudnicki, 1978; Dublyansky, 1980),

- solution by slow convection/circulation (Quinif, 1973), 


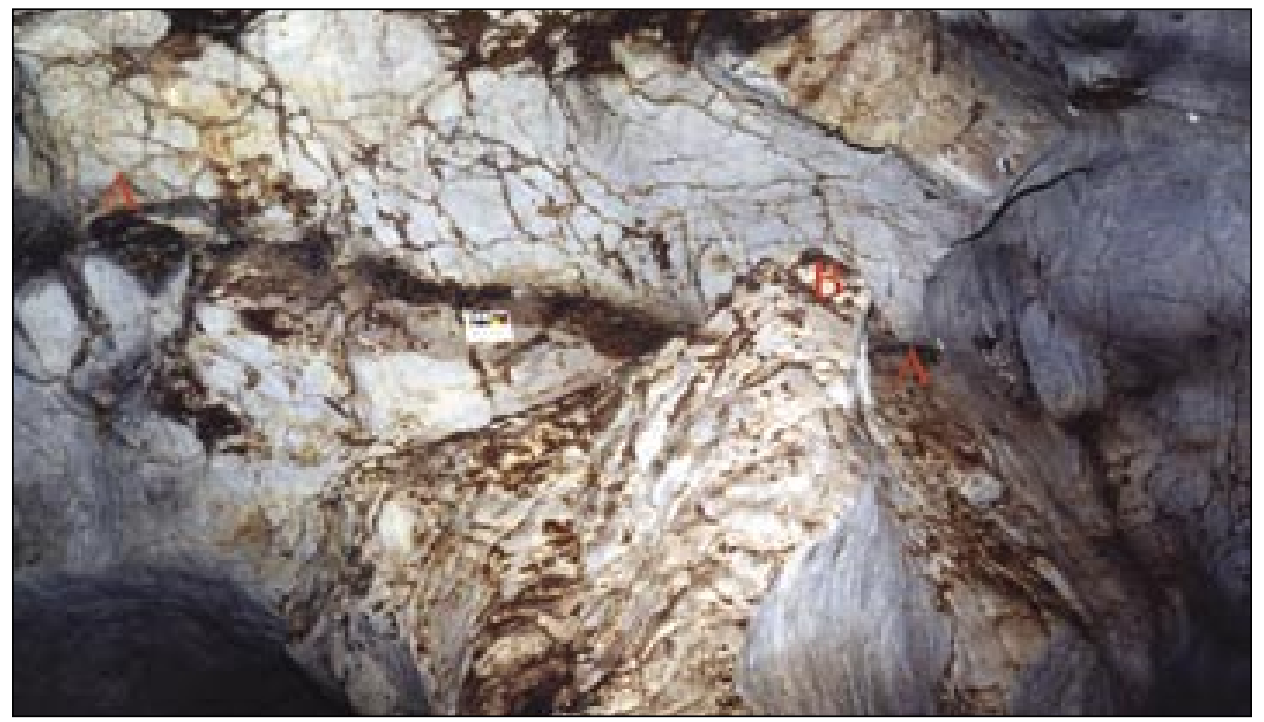

Fig. 17: A pseudonotch, Cathedral Cave, Wellington Caves, New South Wales, Australia. Black squares on scale $=10 \mathrm{~mm}$ A- A: Pseudonotch, note how notch is truncated at rich hand side by development of later void. B: Lower remnant of bridge representing all of former tube eroded away to form pseudonotch.

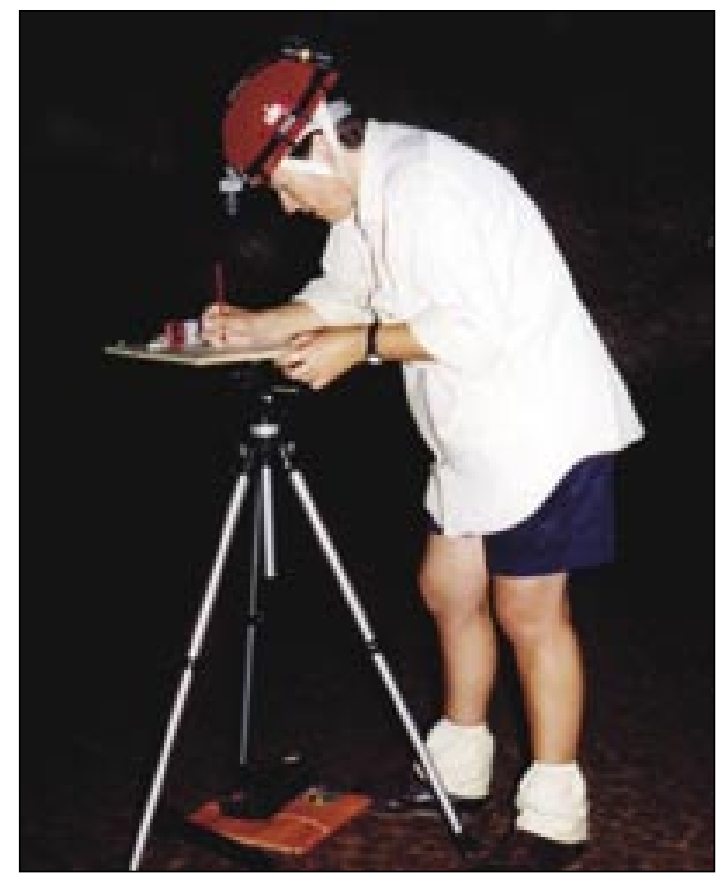

Fig. 18: Claire Cooney using a plane table and laser rangefinder at Wellington Caves. 
- corrosion by compressed air (Lismonde, 2000 ),

- $\quad$ solution by mixing corrosion (Quinif, 1973; Bögli, 1980),

- solution by convection due to density gradients. (Curl, 1996),

- outlet structures for artesian water (Klimchouk, 2000),

- solution by condensation corrosion (Mucke et al., 1983, Adura et al., 2002),

- $\quad$ solution in the salt/fresh water mixing zone (Mylroie et al., 1995),

- erosion producing a "symmetrically scoured pothole" (Dunlop, 1979).

While quite a range of processes have been proposed, it is important to note that all but the last envisage that slow moving fluids (or vapours) were responsible for solution and most involve some form of convection. This suggests that rising (i.e. by per ascensum speleogenesis, sensu Ford, 1995) or mixing waters form cupolas. Given the poor state of knowledge about the actual characteristics of cupolas, it is probably premature to attempt to choose between the various proposed origins except on theoretical grounds.

It is distinctly possible that both cupolas and bellholes are polygenetic, with more than one of the above processes being responsible, depending upon the particular situation. The comments by Mylroie et al. (1995) concerning the similarity between speleogens in their water-mixing zone caves and those found in hydrothermal caves suggest that this may well be the case.

A problem that exists with the recognition of ancient thermal and hydrothermal caves is also

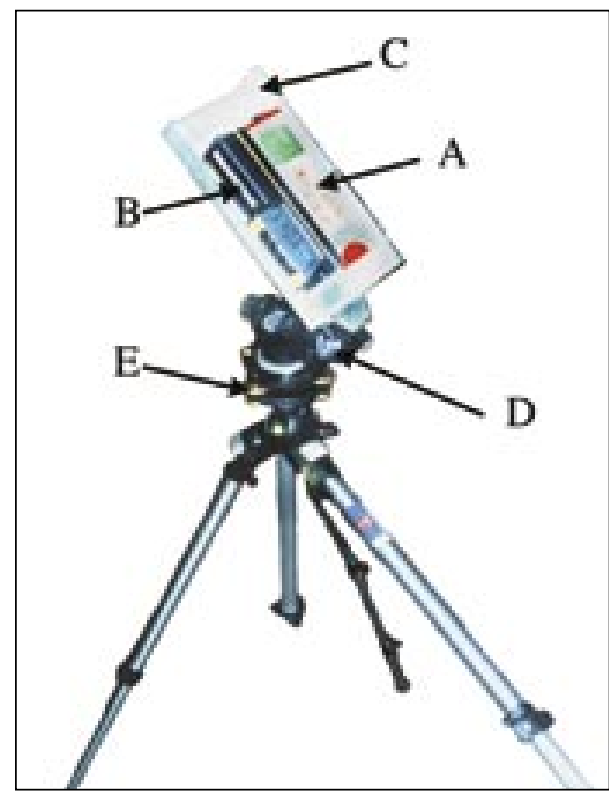

Fig. 19: Section-measuring instrument.
A: Laser rangefinder
B: Digital clinometer
C: Mounting bracket
D: Geared tripod head
E: Levelling Plate.

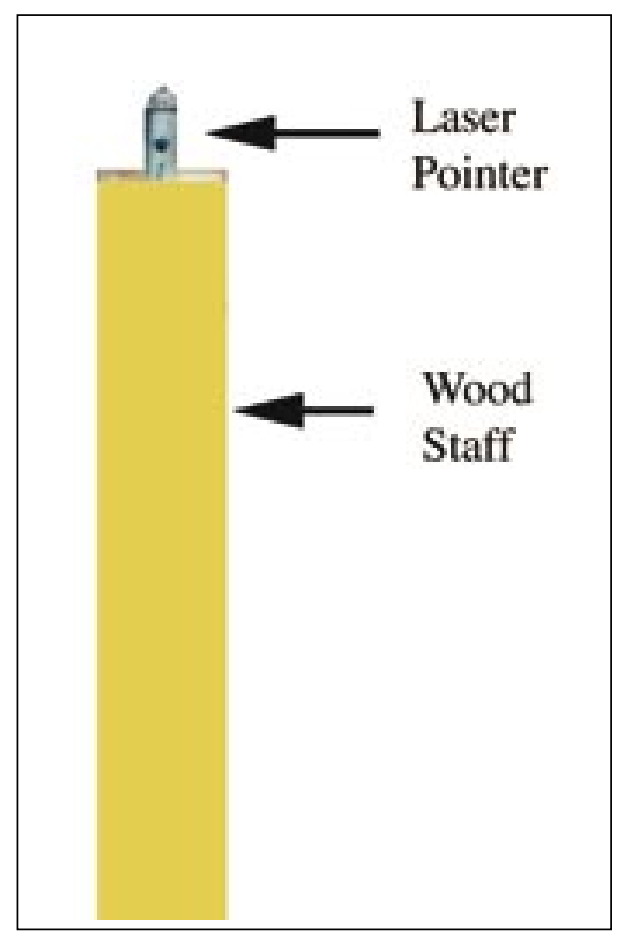

Fig. 20: Sight pole with laser pointer mounted in top. 
important when considering the origin of cupolas. While overall cave morphology and a poor relationship with surface hydrology may be good indicators for the non-meteoric origin of a cave, mineralogical and stable isotope evidence (and proximity to known thermal activity) is usually seen as necessary for the conclusive identification of caves with thermal/hydrothermal origin. This type of evidence can be completely removed by the progress of time. While crystal coatings may remain intact in many of the caves of the Buda Hills in Hungary, those lining the spherical niches of Sátorköpuszta Cave are in the process of falling off. With the mineral evidence removed or degraded by the progress of time and the regional thermal activity gone, it would be difficult to support a case for the thermal origin of these Hungarian caves. This is the situation with the origin of most of the cupolas in eastern Australia, if they did have a thermal or hydrothermal origin, then the critical evidence has been largely lost and the "fire" went out many millions of years ago.

\section{SOLVING THE TROUBLES WITH CUPOLAS}

While there is a clear need for theoretical work into the physical and chemical processes that are likely to produce cupolas, the lack of good field data needs to be urgently addressed. What we need to know is the morphology, taxonomy and natural history (or ecology) of cupolas. The present lack of field data does not provide a good basis for the development of higher level work, let alone allow it to be tested against the real world. Progress can only begin with people in caves carefully observing, measuring and recording.

\section{Gross Morphology}

Establishing the range of gross morphologies and the dimensions of cupolas are essential first steps, as they will allow for comparison and classification. This can best be achieved by measuring a "floor" plan and a series of sections.

Given that points on the walls and ceilings are mostly practically inaccessible, the efficient method would be to survey the plan and sections using a reflectorless laser total station. Digital data could be directly recorded in the field and efficiently processed. This is however an expensive option.

When measuring cupolas in eastern Australia I have been using less capital intensive, although more labour intensive, methods. Plans are drawn in the cave at a scale of 1:100 on a plane table mounted on a photographic tripod using a laser rangefinder (Leica Disto) as an alidade (Figure 18). Sections are measured using a laser rangefinder (Leica Disto) and a digital clinometer (Smarttool) mounted together on an aluminium bracket. The bracket is mounted on a geared photographic tripod head (Manfrotto MF410). A levelling plate (Manfrotto MF 338) is inserted between the geared head and the tripod to enable precise levelling of the instrument (Figure 19). One additional piece of equipment that has proved to be useful is a sight pole with a laser pointer mounted in its top (Figure 20). This allows points on the cave ceiling (e.g. traces of joints) to be located on plans and assists with locating section measuring stations on the axis of guiding joints.

Elliptical cupolas are best measured using a long section along the guiding joint and series of cross-sections. This has been found to be more difficult in practice than expected. The guiding joints are rarely truly planar or truly vertical in dip and tend not to have an entirely straight strike. As a consequence the line of section and the guiding structure are usually not completely aligned. 


\begin{tabular}{|c|c|c|c|c|c|c|}
\hline CAVE NAME & REGION & COUNTRY & TYPE & HOST & $F I G$ & REFERENCE \\
\hline Fourneau & Somme-Leuze & Belgium & & & A & Quinf, 1973 \\
\hline Nettine & Somme-Leuze & Belgium & & & $\mathrm{A}$ & Quinf, 1973 \\
\hline Bankovitsa & Karloukovo & Bulgaria & & & $\mathrm{B}$ & Muke et al., 1983 \\
\hline Orlova Chouka & Dobroudja & Bulgaria & & & $\mathrm{C}$ & Muke et al., 1983 \\
\hline Šupljana & Plitvice & Croatia & & $\mathrm{L}$ & $\mathrm{D}$ & $*$ \\
\hline Koneprusy Caves & Bohemia & Czech Republic & & $\mathrm{L}$ & $\mathrm{E}$ & P. Bosak, pers comm \\
\hline Stratinska & Bohemia & Czech Republic & & $\mathrm{M}$ & $\mathrm{E}$ & V. Cilek, pers comm \\
\hline Bicze skala & Moravia & Czech Republic & & $\mathrm{L}$ & $\mathrm{F}$ & Muke et al., 1983 \\
\hline Amaterska & Moravia & Czech Republic & & $\mathrm{L}$ & $\mathrm{F}$ & V. Cilek, pers comm \\
\hline Ruducke propadani & Moravia & Czech Republic & & $\mathrm{L}$ & $\mathrm{F}$ & V. Cilek, pers comm \\
\hline Aven Noel & Ardeche & France & & $\mathrm{L}$ & $\mathrm{G}$ & Lismonde, 2000 \\
\hline St-Marcel & Ardeche & France & & $\mathrm{L}$ & $\mathrm{G}$ & Lismonde, 2000 \\
\hline La Balme & Isere & France & & $\mathrm{L}$ & $\mathrm{H}$ & Lismonde, 2000 \\
\hline Champignons & Provence & France & Hypogenic & $\mathrm{L}$ & I & Adura et al., 2002 \\
\hline Adaouste & Provence & France & Hypogenic & $\mathrm{L}$ & $\mathrm{I}$ & Adura et al., 2002 \\
\hline Saint-Eucher & Vaucluse & France & & $\mathrm{L}$ & $\mathrm{J}$ & Bigot, 1999 \\
\hline de la Vapeur & Ariege & France & $\mathrm{H} /$ thermal & & $\mathrm{K}$ & Bigot, 1999 \\
\hline Darchenhole Syrau & Vogtland & Germany & & $\mathrm{L}$ & $\mathrm{L}$ & Muke et al., 1983 \\
\hline Herammschohle & Harz Mts. & Germany & & $\mathrm{L}$ & $\mathrm{M}$ & Muke et al., 1983 \\
\hline unnamed large caves & Harz Mts. & Germany & & $\mathrm{G}$ & $\mathrm{M}$ & Muke et al., 1983 \\
\hline Satorkopuszta & Pilisz Mts. & Hungary & Thermal & $\mathrm{L}$ & $\mathrm{N}$ & * Rudnicki, 1978 \\
\hline Topolca Lake & Lake Baliton & Hungary & Thermal & $\mathrm{L}$ & 0 & $*$ \\
\hline Pál-Völgyi & Buda Hills & Hungary & Thermal & $\mathrm{L}$ & $\mathrm{P}$ & * Kiss \& Takacsne-Bolner, 1987 \\
\hline Josef-Hegy & Buda Hills & Hungary & Thermal & $\mathrm{L}$ & $\mathrm{P}$ & $*$ \\
\hline Ferenc-Hegy & Buda Hills & Hungary & Thermal & $\mathrm{L}$ & $\mathrm{P}$ & Rudnicki, 1978 \\
\hline Batori & Buda Mts. & Hungary & Thermal & $\mathrm{L}$ & $\mathrm{P}$ & Rudnicki, 1978 \\
\hline Frassassi Gorge & Umbria/Marché & Italy & Hypogene & & Q & Galdenzi \& Menichetti, 1995 \\
\hline Parrano Gorge & Umbria/Marché & Italy & Hypogene & & Q & Galdenzi \& Menichetti, 1995 \\
\hline Acquasanta Terme & Umbria/Marché & Italy & Hypogene & & Q & Galdenzi \& Menichetti, 1995 \\
\hline Monte Cucco & Umbria/Marché & Italy & Hypogene & & Q & Galdenzi \& Menichetti, 1995 \\
\hline Pozzi della Piana & Umbria/Marché & Italy & Hypogene & & Q & Galdenzi \& Menichetti, 1995 \\
\hline Koloczec Hill & Krakow & Poland & Thermal & $\mathrm{L}$ & $\mathrm{R}$ & * Rudnicki, 1978 \\
\hline Ciemna & Krakow & Poland & Thermal & $\mathrm{L}$ & $\mathrm{R}$ & * Gradzinski, 1962 \\
\hline Smocza & Krakow & Poland & Thermal & $\mathrm{L}$ & $\mathrm{R}$ & * \\
\hline Lotietka & Krakow & Poland & Thermal & $\mathrm{L}$ & $\mathrm{R}$ & $*$ \\
\hline Towarni Hill & Krakow & Poland & Thermal & $\mathrm{L}$ & $\mathrm{R}$ & $*$ \\
\hline Dziura & Tatra Mts. & Poland & Thermal & $\mathrm{L}$ & $\mathrm{S}$ & Bac-Moszaszwili \& Rudnicki, 1978 \\
\hline Coliboaia & Bihor Mts. & Romania & & & $\mathrm{T}$ & Muke et al., 1983 \\
\hline Bakhardenskaya & Cauasus & Russia & $\mathrm{H} /$ thermal & L\&G & $\mathrm{NA}$ & Dublyanskiy,1980 \\
\hline Proval Abyss & Cauasus & Russia & $\mathrm{H} /$ thermal & & NA & Dublyanskiy,1980 \\
\hline Belianska & Belianska Tartra & Slovakia & $?$ & $\mathrm{~L}$ & $\mathrm{U}$ & $*$ \\
\hline Demanovska Ice & Low Tartra & Slovakia & relict & $\mathrm{L}$ & $\mathrm{V}$ & $*$ \\
\hline Ochtinska Aragonite & & Slovakia & $?$ & $\mathrm{~L}$ & $\mathrm{~W}$ & $*$ \\
\hline Predjama & Kras & Slovenia & relict & $\mathrm{L}$ & $X$ & $*$ \\
\hline Račiška & Kras & Slovenia & ? & $\mathrm{L}$ & $\mathrm{X}$ & $*$ \\
\hline Mlinky & W Ukraine & Ukraine & Artesian & $\mathrm{G}$ & $\mathrm{Y}$ & $*$ \\
\hline Slavka & W Ukraine & Ukraine & Artesian & $\mathrm{G}$ & $\mathrm{Y}$ & $*$ \\
\hline
\end{tabular}

Table 1: Caves in Europe reported to contain cupolas, see figure 14. 


\section{Micromorphology and speleogens}

Micromorphology and speleogens are best studied by detailed examination, measurement and photography. 1:100 scale mapping and sections allow the locations of many small features to be documented. Stereo photography and photographic "scans" have also proved to be very useful. Checklists need to be produced to show which speleogens are developed in which caves, with which types of cupolas and the degree of speleogen development.

\begin{tabular}{|c|c|c|c|c|c|c|}
\hline CAVE NAME & REGION & COUNTRY & TYPE & HOST & & REFERENCE \\
\hline \multicolumn{7}{|l|}{ AMERICAS } \\
\hline Triple Shaft & $\begin{array}{l}\text { San Salvador } \\
\text { Is }\end{array}$ & Bahamas & Flank Margin & & & Mylroie et al.1995 \\
\hline USA & & STATE & \multicolumn{2}{|c|}{ SEE FIGURE 14} & FIG & \\
\hline Wind \& Jewel + & Back Hills & Sth Dakota & Hypogene & LS & A & A. Palmer pers comm \\
\hline Carlsbad + & $\begin{array}{l}\text { Guadalupe } \\
\text { Mts. }\end{array}$ & $\begin{array}{l}\text { Mew } \\
\text { Mexico }\end{array}$ & Sulfuric Acid & LS & B & Hill, 1987 \\
\hline Cave of Winds + & Rocky Mts. & Colorado & & & $\mathrm{C}$ & A. Palmer pers comm \\
\hline Groaning Cave + & $\begin{array}{l}\text { White River } \\
\text { Plateau }\end{array}$ & Colorado & & & $\mathrm{D}$ & A. Palmer pers comm \\
\hline $\begin{array}{l}\text { Horsethief-Big- } \\
\text { horn }+\end{array}$ & $\begin{array}{l}\text { Montana- } \\
\text { Wyoming }\end{array}$ & & & & $\mathrm{E}$ & A. Palmer pers comm \\
\hline Lewis and Clark + & & Montana & & & $\mathrm{F}$ & A. Palmer pers comm \\
\hline Timpanogos + & $\begin{array}{l}\text { Low Eleva- } \\
\text { tion Caves }\end{array}$ & Utah & & & G & A. Palmer pers comm \\
\hline $\begin{array}{l}\text { Lehman, Old Man's } \\
\text { Cave + }\end{array}$ & Utah border & Nevada & & & $\mathrm{H}$ & A. Palmer pers comm \\
\hline $\begin{array}{l}\text { Horseshoe Mesa/ } \\
\text { Cave of the Domes } \\
+\end{array}$ & $\begin{array}{l}\text { Grand } \\
\text { Canyon }\end{array}$ & & & & $\mathrm{J}$ & A. Palmer pers comm \\
\hline Caverns of Sonora + & & Texas & & & $\mathrm{K}$ & A. Palmer pers comm \\
\hline \multicolumn{7}{|l|}{ AFRICA } \\
\hline CAVE NAME & & $\begin{array}{l}\text { COUN- } \\
\text { TRY }\end{array}$ & & & & \\
\hline Rar Es Skhoun & Bibans & Algeria & Thermal & & & Collignon, 1983 \\
\hline \multicolumn{7}{|l|}{ ASIA (CENTRAL) } \\
\hline numerous caves & Tyan-Shan & & & & & Dublyanskiy,1980 \\
\hline
\end{tabular}

Table 2: Caves with cupolas reported from the Americas, Africa and Asia. 


\section{Taxonomy}

I have introduced here an initial, qualitative taxonomy of cupolas. With more field data it should be possible to supersede this with a numerical system based on geometric data. Axial ratios and measurements of inflation, spehericity etc. may prove useful in distinguishing between natural populations of these forms. The main requirement is a sufficiently large and representative data set.

\section{Mineralogy and Isotopic Studies}

Where they survive, minerals deposited close to the time of cupola excavation can provide important clues as to the mechanism of formation. These minerals may be crystals of carbonates, sulfates, sulfides or even quartz and deposits of clays and other silicates. While such deposits will be abundant in recently active thermal caves, they are likely to survive only as tiny remnant deposits in older caves, particularly where there has been stream capture or significant speleothem deposition.

The mineralogy, trace element composition and isotopic signature of these deposits should provide some indication as to the temperature and chemistry of the fluids from which they were deposited and hence provide an indication of the conditions at the time of cupola formation.

\begin{tabular}{|l|l|l|l|l|l|l|}
\hline \multicolumn{1}{|c|}{ CAVE NAME } & \multicolumn{1}{|c|}{$\begin{array}{c}\text { REGION/ } \\
\text { KARST }\end{array}$} & STATE & $\begin{array}{c}\text { TYPE/ } \\
\text { ORIGIN }\end{array}$ & $\begin{array}{c}\text { HOST } \\
\text { ROCK }\end{array}$ & $\begin{array}{c}\text { FIG } \\
\#\end{array}$ & \\
\hline Ashford Main & Ashford & NSW & $?$ & LS & 15 & $*$ \\
\hline Mendip & Bungonia & NSW & $?$ & LS & 15 & Bauer \& Bauer, 1998 \\
\hline Lannigan's & Colong & NSW & $?$ & LS & 15 & $*$ \\
\hline Mammoth & Jenolan & NSW & $?$ & LS & 15 & $*$ Osborne, 1999 \\
\hline Orient & Jenolan & NSW & $?$ Thermal & LS & 15 & $*$ Osborne, 1999 \\
\hline Pool of Cerberus & Jenolan & NSW & $?$ Thermal & LS & 15 & $*$ Osborne, 1999 \\
\hline River & Jenolan & NSW & $?$ Thermal & LS & 15 & $*$ Osborne, 1999 \\
\hline Temple of Baal & Jenolan & NSW & $?$ Thermal & LS & 15 & $*$ Osborne, 1999 \\
\hline Deep Hole & Walli & NSW & $?$ Thermal & LS & 15 & $*$ \\
\hline Cathedral & Wellington & NSW & $?$ Thermal & LS & 15 & $*$ \\
\hline Phosphate Mine & Wellington & NSW & $?$ Thermal & LS & 15 & $*$ \\
\hline Basin & Wombeyan & NSW & $?$ & M & 15 & $*$ \\
\hline Jersey & Yarrangobilly & NSW & $?$ & LS & 15 & $*$ \\
\hline Yessabah Bat & Yessabah & NSW & $?$ Artesian & LS & 15 & $*$ Osborne, 2001 \\
\hline Cathedral & Naracoorte & SA & $?$ & LS & 15 & $*$ \\
\hline Tomato & Naracoorte & SA & $?$ & LS & 15 & J. Rowling pers comm \\
\hline Tantanoola & Tantanoola & SA & $?$ & LS & 15 & $*$ \\
\hline * Observed by author & & & & \\
\hline
\end{tabular}

Table 3: Caves with cupolas in Australia. 


\section{Natural History}

Cupolas do not exist in isolation, but are sections of caves developed in rocks within landscapes and tectonic zones. While there is some indication that cupolas do occur in particular types of caves there is insufficient known about this and very little known about where in the caves cupolas occur.

\section{Where are caves with cupolas?}

It is important to gain an understanding of the geological, geomorphic, tectonic and climatic settings of caves in which cupolas are developed. Table 1 indicates that cupolas occur in caves developed in a range of geological, geomorphic and tectonic settings. But will more data produce a different result? Sufficient good data needs to be collected to enable questions such as the following and more to be answered: -

- Do cupolas develop independently of host rock type, age and attitude of bedding, or are they more common in certain rocktypes?

- Are cupolas more common in fold belts than in basins?

- Is there any relationship between cupolas and climate?

- Is there any relationship between cupola development and thermal or volcanic activity?

\section{What type of caves do cupolas form in?}

Cupolas seem to occur in caves that are somewhat different. Since most workers tend to classify cave types genetically or environmentally rather than morphologically, there is some difficulty in putting a definite handle on just what characteristics caves with cupolas have in common. Describing caves as thermal, hydrothermal, artesian, hypogene or flank margin does not allow easy morphological comparisons to be made. Use of descriptive terms like network, maze, ramiform, or the morphological list provided by Dublyansky (1997) and numerical approaches such as the "cave index" of Klimchouk (1996) will allow more useful comparison, particularly if cupolas are found to be polygenetic. Sufficient good data needs to be collected to enable this issue to be investigated and resolved.

\section{Do cupolas occur in particular parts of caves?}

Dublyansky (2000) noted that cupolas are usually found in the upper parts of bush-like caves such as those in the Buda Hills of Hungary. There is insufficient data to know if this is the general case. Data needs to be collected to answer questions like: -

- are cupolas more common in the upper or lower parts of caves?

- do cupolas occur in the middle or at the ends of horizontal passages?

- are cupolas common at the junctions of passages?

- is there any relationship between cupolas and cave entrances?

\section{When did cupolas form?}

It should be possible to determine the age of cupolas relative to other cave voids (and to other cupolas) by examining crosscutting relationships. My initial work at Jenolan and Wellington Caves is suggesting that in these caves elliptical cupolas predate hemispherical cupolas and that the cathedrals formed last. There is also some indication that E-W (across strike) development preceded $\mathrm{N}-\mathrm{S}$ (along strike) development.

Detailed observations should allow development of a speleogenetic history for caves with cupolas. This will greatly aid understanding of the process by which cupolas form. If this relative history can be tied down by absolute dating it may be possible to find links with regional scale geological 
events e.g. volcanic and thermal events or marine transgressions that may relate to the excavation of the cupolas.

\section{ACKNOWLEDGEMENTS}

A number of caves with cupolas in central Europe were examined in 2001 while the author was undertaking a special studies program from the University of Sydney. Considerable assistance was gratefully received from: - Professor R. Gradzinski, Dr M. Gradzinski \& Dr A. Tyc, Poland; Drs P. Bosak \& V. Cilek, Czech Republic; Dr P. Bella, Slovakia; Dr T. Slabe, Slovenia; Dr S. Leel-Ossy, Mr P. Zentay, Thomas \& Melinda, Hungary; Dr A. Klimchouk, Ukraine. Mrs M. Kranjc is thanked for her assistance in the library of the Karst Research Institute, Postojna, Slovenia. Professor A. Palmer, State University of New York, Oneonta provided images and information on cupolas in the USA. K.G. Grimes and the editors of Kras i speleologia are thanked for permission to reproduce diagrams.

A University of Sydney Sesquicentenary Grant supported initial cupola survey work at Jenolan Caves in 2003. Survey work in Cathedral Cave, Wellington Caves was supported by a research contract from Wellington Council.

David Colchester assisted with fieldwork at Jenolan Caves and Claire Cooney assisted with fieldwork at Wellington Caves. Alan Pryke and members of the Sydney University Speleological society assisted with fieldwork at Colong Caves and Jill Rowling and members of the Sydney Speleological Society assisted with fieldwork at Walli Caves. Penney Osborne critically read the drafts and helped with field measurements.

The National Parks and Wildlife Service of New South Wales is thanked for permission to undertake research at Bungonia, Colong and Yarrangobilly Caves. The Jenolan Caves Reserve Trust is thanked for permission to undertake research and for providing accommodation at Jenolan and Wombeyan Caves. Wellington Council is thanked for permission to undertake research and for assistance and accommodation at Wellington Caves and the Sydney Speleological Society is thanked for permitting access to Walli Caves.

\section{REFERENCES}

Audra, P., Bigot, J-Y. \& Mocochain, L., 2002. Hypogenic caves in Provence (France): Specific features and sediments. Acta carsologica. 31(3): 33-50.

Bac-Moszaswill, M. \& Rudnicki, J., 1978. O mozliwosei hydrotermalnej genezy jaskini Dziura w Tatrach. Kras i speleologia. 2(XI): 84-91.

Bakalowicz, M. J., Ford, D. C., Miller, T.E., Palmer, A. N. \& Palmer, M.V., 1987. Thermal genesis of dissolution caves in the Black Hills, South Dakota. Bulletin of the Geological Society of America. 99, 729-738.

Bella, P. \& Urata, K., 2002. Oválne stropné kupolovité a komínovité vyhĺbeniny v Jasovskej Jaskyni. Aragonit. 4: 4-7.

Bögli, A., 1980. Karst hydrology and physical speleology, Springer Verlag, Berlin.

Bigot, J.Y., 1999. Les coupoles et le paléokarst de la grotte de Saint-Eucher (Beaumont-de-Pertuis, Vaucluse). Internet: - http://karst.PlanetResources.net/le_paleokarst.htm 
Collignon, 1983. Spéléogenèse hydrothermal dan les Bibans (Atlas Tellien-Nord de l'Algérie). Karstologia 2 (1983- 2eme semestre): 45-54.

Curl, R.L., 1966. Cave conduit enlargement by natural convection. Cave Notes. 8(1): 2-6.

Dogwiler, T.J., 1998. Analysis of bell hole morphology and distribution: A tool for evaluating formational processes. MSc Thesis, Mississippi State University, unpbl.

Delbridge, A., Ed, 1981. The Macquarie Dictionary. Macquarie Library, St Leonards.

Dreybrodt, W \& Franke, H.W., 1994. Joint-controlled solution pockets (Laugungskolke) in ceilings of limestone caves: a model of their genesis, growth rates and diameters. Zeitschrift fur Geomorphologie, N.F. 38(2): 239-245

Dublyansky, V.N. 1980. Hydrothermal karst in the alpine folded belt of the southern parts of U.S.S.R. Kras i Speleologia. 3: 18-36.

Dublyansky, Y.V., 1997. Transition between hydrothermal and cold-water karst. Proceedings of the 12th international Congress of Speleology, 1997, Switzerland 2: 267-270.

Dublyansky, Y.V. 2000. Hydrothermal speleogenesis: its settings and peculiar features. in A. B. Klimchouk, D.C. Ford, A. N. Palmer \& W. Dreybrodt eds, Speleogenesis: Evolution of Karst Aquifers, National Speleological Society, Huntsville: 292-297.

Dunlop, B.T., 1979. Jenolan Caves, 11th Edition. (New South Wales Department of Tourism, Sydney) 96p.

Ford, D.C., 1995. Paleokarst as a target for modern karstification. Carbonates and Evaporites. 10(2): 138-147.

Field, M.S., 1999. A Lexicon of Cave and Karst Terminology with Special Reference to Environmental Karst Hydrology. United States Environment Protection Agency, Washington.

Fletcher, B., 1950. A History of Architecture on the Comparative Method. B.T. Batsford, London.

Galdenzi \& Menichetti, 1995. Occurrence of hypogenic caves in a karst region: Examples form central Italy. Environmental Geology. 26:29-47.

Gradzinski, R., 1962. Origin and development of subterranean Karst in the Southern part of the Krakow Upland. Roczink Polskiego Towarzystwa Geologicznego. 32: 429-492.

Hill, C.A, 1987. Geology of Carlsbad Cavern and other caves in the Guadalupe Mountains,

New Mexico and Texas. New Mexico Bureau of Mines and Mineral Resources.

117: 1-150.

Jennings, J.N., 1985. Karst Geomorphology. Basil Blackwell, Oxford.

Kempe, S., 1975. "Facetten" and "Laugdecken", the typical morphology of caves developing in standing water. Annales de Speleology. 4: 705-708.

Klimchouk, A.B, 1996. Gypsum karst of the western Ukraine. International Journal of Speleology. 25(3-4): 263-278.

Klimchouk, A.B, 2000. Speleogenesis of the Great Gypsum Mazes of the Western Ukraine. . in A. B. Klimchouk, D.C. Ford, A. N. Palmer \& W. Dreybrodt eds, Speleogenesis: Evolution of Karst Aquifers, National Speleological Society, Huntsville: 261-273.

Klimchouk A. \& Andrejchouk, V., 1996. Breakdown development in cover beds, and landscape features induced by intrastratal gypsum karst. International Journal of Speleology. 25(3/4): 127-114.

Lauritzen, S-E. \& Lundberg, J., 2000. Solutional and erosional morphology. in A. B. Klimchouk, D.C. Ford, A. N. Palmer \& W. Dreybrodt eds, Speleogenesis: Evolution of Karst Aquifers, 
National Speleological Society, Huntsville: 408-426.

Lismonde, B., 2000. Corrosion des couples de plafond par les fluctuations de pression de l'air emprisonne. Karstologia. 35: 39-46.

Little, W., Fowler, H.W. \& Coulson, J., 1936. The Shorter Oxford Dictionary on Historical Principles, Second Edition. Clarendon Press, Oxford.

Mucke, B., Vilker, R. \& Wadewitz, S., 1983. Cupola formation in occasionally inundated cave roofs. Proceedings of the European Regional Conference on Speleology, Sofia, Bulgaria 22-28 September 1980. 2:129-132.

Mylroie, J.E., Carew, J.L. \& Vacher, H.l., 1995. Karst development in the Bahamas and Bermuda. Geological Society of America Special Paper. 300: 251-267.

Osborne, R.A.L., 1996. Vadose weathering of sulfides and limestone cave development-Evidence from eastern Australia. Helictite. 34(1): 5-15.

Osborne, R.A.L., 1999. The origin of Jenolan Caves: Elements of a new synthesis and framework chronology. Proceedings of the Linnean Society of New South Wales. 121: 1-26.

Osborne, R.A.L., 2001. Halls and narrows: Network caves in dipping limestone, examples from eastern Australia. Cave and Karst Science. 28 (1): 3-14.

Panos, V., 2001. Karsologicks a Speleologicka Terminologie. Knizne Centrum, Zilna.

Quinif, Y., 1973. Contribution à l'étude morphologique des coupoles. Annales Spéléologie. 28(4): 5654-573.

Rudnicki, J., 1978. Role of convection in shaping subterranean karst forms. Kras I speleologia. 2(11): 92-100.

Slabe, T., 1995. Cave Rocky Relief and its Speleologenetical Significance. Zbirka ZRC, Ljubljana. 